PONTIFÍCIA UNIVERSIDADE CATÓLICA do RIO dE JANEIRO

\title{
Aplicação da Pesquisa de Clima Organizacional em um Clube Esportivo
}

\author{
Laísa de Lima Freitas
}

Trabalho de Conclusão de Curso

Centro de ciências sociais - CCS

DePARTAMENTO dE AdMINISTRAÇÃO

Graduação em Administração de Empresas 


\section{Laísa de Lima Freitas}

\section{Aplicação da Pesquisa de Clima Organizacional em um Clube Esportivo}

Trabalho de Conclusão de Curso

Trabalho de Conclusão de Curso, apresentado ao programa de graduação em Administração da PUC-Rio como requisito parcial para a obtenção do titulo de graduação em Administração.

Orientador: Edmundo Eutrópio Coelho de Souza 
"Muitas das coisas mais importantes do mundo foram conseguidas por pessoas que continuaram tentando quando parecia não haver mais nenhuma esperança de sucesso". Dale Carnegie 


\section{Agradecimentos}

A minha sobrinha Júlia, por ser minha principal motivação a estudar e trabalhar sempre em busca do meu melhor resultado. A minha irmã Laís e minha prima Leticia por serem presentes na minha vida e exemplos de pessoas integras, bondosas e, principalmente, inteligentes. Aos meus pais, que me proporcionaram a melhor educação de base possível para as condições da época e que me fizeram enxergar o quanto é necessário estudar. Aos amigos que conquistei na faculdade que tornaram meus dias de aulas mais leves e divertidos, o que me motivava a não desistir. Ao meu mestre Edmundo que por exatos 2 anos permaneceu firme no propósito de me ajudar a concluir o melhor trabalho de todos os tempos. Ao Clube Esportivo, que me permitiu utilizar dados internos para realizar esse trabalho. E por último a todos os Brasileiros, responsáveis por pagar seus impostos em dia e poder proporcionar ao Governo criar e manter projetos como o ProUni que garantem que pessoas de menor renda cursem uma faculdade de excelência com bolsa integral. Meu muito obrigada a todos! 


\section{Resumo}

FREITAS, Laísa de Lima. Aplicação da Pesquisa de Clima Organizacional em um Clube Esportivo. Rio de Janeiro, 2017. 53 p. Trabalho de Conclusão de Curso - Departamento de Administração. Pontifícia Universidade Católica do Rio de Janeiro.

Este artigo teve por objetivo aplicar uma pesquisa de clima organizacional em um Clube Esportivo, onde a atividade principal é o futebol de campo, com a finalidade de identificar oportunidades de melhorias na gestão da recém-criada área de Recursos Humanos da organização e propor um plano de ação adequado à realidade da empresa e planejado para solucionar os problemas identificados. Assim como na sociedade, toda empresa tem sua herança cultural, na qual suas crenças e costumes são repassados aos colaboradores. Com base nisso, buscou-se conhecer a percepção que os colaboradores possuem do clima da organização e a imagem que esse clima da empresa reproduz em seu imaginário.

Palavras-chave: Pesquisa de Clima, Recursos Humanos, Clube Esportivo, Clima Organizacional

\section{Abstract}

FREITAS, Laísa de Lima. Work Environment Survey Application in a Sports Club. Rio de Janeiro, 2017. 53 p. Trabalho de Conclusão de Curso Departamento de Administração. Pontifícia Universidade Católica do Rio de Janeiro.

This article aims at applying a work environment survey in a sports club in which the major activity is soccer. Its main goal was to obtain valuable information in order to identify improvement opportunities in the recently created Human Resources department, besides drawing a suitable action plan to solve the identified problems.

Similarly to the society, each company presents a cultural heritage with what the habits and beliefs are spread out through the employees. Based on that, the survay was accomplished in order to evaluate the image workers have of the organizational climate, the image it produces on their mindset and, most importantly, the impact it causes in their performance.

Key-words: Work environment survey, Human Resources,Sports club, Organizational climate 


\section{Sumário}

1 Introdução

2 Contexto e realidade investigada

3 Diagnóstico da situação problema e oportunidade 9

3.1. Aprovação da Diretoria 9

3.2. Planejamento da Pesquisa 10

3.3. Divulgação da Pesquisa 12

3.4. Aplicação da Pesquisa e Tabulação dos Dados 13

4 Análise da situação e proposta de solução 16

4.1. Panorama Geral 16

4.2. Análise dos Pontos Relevantes e Plano de Ação 18

4.2.1. Falta de Cooperação entre Departamentos 21

4.2.2. Falta de Treinamento para os Funcionários 23

4.2.3. Qualificação da Liderança na Gestão de Pessoas 25

4.2.4. Falta de Comunicação Interna 27

4.2.5. Falta de Ferramentas de Trabalho 29

4.2.6. Fatores de Desmotivação 31

4.2.6.1. Falta de Reconhecimento 33

4.2.6.2. Regularização de Leis Trabalhistas 34

5 Conclusões e contribuições do estudo 35

6 Referências $\quad 39$

Anexo 1: Divulgação - O que é Pesquisa de Clima? 41

Anexo 2: Divulgação - Qual a importância e objetivo do clube? 42

Anexo 3: Divulgação - Como será a pesquisa? 43 


\section{Lista de figuras}

Figura 1: Gráfico do gênero dos respondentes............................................. 17

Figura 2: Gráfico com a idade dos respondentes em anos.............................. 17

Figura 3: Gráfico do estado civil dos respondentes. ..................................... 17

Figura 4: Gráfico com o tempo de empresa dos respondentes em anos........... 18

Figura 5: Gráfico com a renda familiar dos respondentes em salários mínimos (novembro,2016) ...................................................................... 18

Figura 6: Modelo ilustrativo do Método PDCA .............................................. 20

Figura 7: Gráfico da percepção dos respondentes quanto a cooperação entre

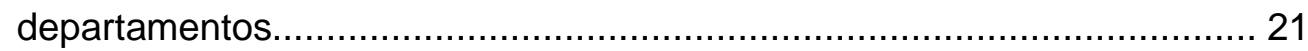

Figura 8: Gráfico da percepção dos respondentes quanto ao relacionamento entre funcionários. 22

Figura 9: Gráfico da percepção dos respondentes em quanto a empresa investe em treinamento. 23

Figura 10: Gráfico da percepção dos respondentes em quanto a empresa investe no aprendizado contínuo.

Figura 11: Gráfico da percepção dos respondentes em relação ao gestor imediato ser receptivos a mudanças. 25

Figura 12: Gráfica da percepção dos respondentes em relação a ser respeitado pelo gestor 26

Figura 13: Gráfico da percepção dos respondentes quanto a comunicação interna. 28

Figura 14: Gráfico da percepção dos respondentes referente a abertura da empresa para receber críticas. 
Figura 15: Gráfico da percepção dos respondentes da segunda sede em relação as condições ambientais de trabalho......

Figura 16: Gráfico da percepção dos respondentes da sede principal em relação as condições ambientais de trabalho. 30

Figura 17: Gráfico da percepção dos respondentes da sede principal quanto aos fatores que causam desmotivação no trabalho. 32

Figura 18: Gráfico da percepção dos respondentes da segunda sede quanto aos fatores que causam desmotivação no trabalho. 32

\section{Lista de tabelas}

Tabela 1: Percentual definido como "Satisfatório" para cada variável avaliada. 19 


\section{Introdução}

No cenário organizacional contemporâneo, é pré-requisito às empresas que desejam estar na vanguarda e atingirem melhores resultados operacionais possuírem uma área de Recursos Humanos estruturada, bem gerida, atuante e reconhecida pelos colaboradores. $O$ que ainda não fica claro para os funcionários é que essa área, em grandes empresas, geralmente é subdividida em quatro especialidades: Recrutamento e Seleção, Treinamento e Desenvolvimento, Departamento Pessoal e Cargos e Salários.

Aos colaboradores das empresas é complexo assimilar a diferença dessas especialidades, pois há uma linha muito tênue para identificá-las. Sendo assim, para elucidação é possível reunir essas 4 especialidades em duas bem distintas e de fácil explicação.

Recrutamento e Seleção juntamente com Treinamento e Desenvolvimento formam o que se denomina Recursos Humanos, comumente abreviado para $\mathrm{RH}$. Esse é o responsável pela gestão das pessoas, focado em zelar pelas relações humanas e sócio afetivas entre os colaboradores, por meio do desenvolvimento de trabalhos voltados ao lado psicológico visando a cultivar o bom relacionamento entre os funcionários. Além disso, concentra-se por entender o perfil da organização e buscar no mercado o profissional mais adequado à cultura da empresa. Por último, é o principal responsável por reter os melhores talentos, entendendo o que é necessário para fomentar a motivação e o engajamento do funcionário evitando que ele perfaça sua satisfação profissional em outra organização.

Por outro lado, Cargos e Salários, é integrado ao Departamento Pessoal, geralmente denominado como DP. Este departamento tem como objetivo cuidar de toda a parte burocrática relativa à legislação trabalhista vigente, elaborar a folha de pagamento, calcular encargos, manter registros atualizados entre outro. Ademais, visa a manter o equilíbrio 
financeiro da folha de pagamento, garantindo que todas as pessoas com as mesmas atividades e funções dentro da empresa sejam equivalentemente remuneradas.

Como exemplo dessa diferença, é facilmente possível verificar na prática de mercado que empresas de pequeno porte tem o costume de terceirizar esses departamentos, deixando um escritório de contabilidade responsável pelo departamento pessoal, e contratando uma agência de emprego para gerir o básico da área de Recursos Humanos.

Compreendida essa diferença, voltemos ao cerne deste estudo: Pesquisa de Clima Organizacional, uma das ferramentas que ajudam significativamente a área de Recursos Humanos a captar o momento atual da empresa e identificar pontos positivos e de melhoria é a.

Toda empresa tem uma cultura própria, Schein (2003), p.15 traz a seguinte definição de cultura organizacional:

É um conjunto de pressupostos básicos que um grupo
inventou, descobriu ou desenvolveu ao aprender como lidar
com os problemas de adaptação externa e integração
interna e que funcionaram bem o suficiente para serem
considerados válidos e ensinados a novos membros como a
forma correta de perceber, pensar e sentir em relação a
esses problemas. (SCHEIN apud LUZ, 2003, p. 15)

Nesse sentido, LUZ (2003) define que a cultura de uma empresa são os comportamentos e os valores compartilhados por seus colaboradores. E é vital manter a gestão ativa dessa cultura, visto que ela pode fortalecer ou debilitar a organização. É importante saber que essa cultura pode mudar ao longo do tempo por diversos fatores e que essas mudanças nem sempre serão ruins. O principal fator de mudança é a rotatividade dos funcionários: à medida em que gerentes e funcionários se desligam das empresas e outros são contratados para substituí-los, o novo colaborador traz consigo comportamentos e valores que serão, gradativamente, inseridos no grupo. Entretanto se a cultura for bem forte, é possível que mude bem pouco. De qualquer forma, é necessário entender e conhecer as práticas, os hábitos, os comportamentos e os valores éticos e morais do grupo de colaboradores para atuar de forma proativa potencializando os benefícios que esse conjunto traz para o dia a 
dia do colaborador e da organização e ajustando o que precisa ser melhorado para manter a harmonia do grupo.

Bowditch (1992) lembra que existem diferenças importantes entre clima e cultura organizacional. O primeiro é uma medida de até que ponto as expectativas das pessoas sobre como se deve trabalhar, em uma organização, está sendo cumprida, portanto, um indicador de que tais crenças e expectativas estão sendo ou não concretizadas. Já a cultura ocupa-se da natureza, das crenças e expectativas sobre a vida da organização.

Chiavenato (1997) define o clima organizacional como sendo o conjunto de propriedades mensuráveis do ambiente de trabalho percebido, direta ou indiretamente, pelos indivíduos que vivem e trabalham neste ambiente e que influencia a motivação e o comportamento dessas pessoas.

Ele representa o conjunto de sentimentos predominantes numa determinada empresa e, envolve a satisfação dos profissionais tanto com os aspectos mais técnicos de suas carreiras e trabalho quanto aspectos afetivos/emocionais, refletindo em suas relações com os colegas de trabalho, com os superiores e com os clientes de modo geral. É a tendência de percepção que os membros de uma organização possuem a respeito de seu grau de satisfação em relação ao conjunto ou a determinada característica desta organização. (CHIAVENATO, 1997, p. 126).

Para Coda (1992), a Pesquisa de Clima Organizacional é:

Um levantamento de opiniões que caracteriza uma representação da realidade organizacional consciente, uma vez que objetiva retratar o que as pessoas acreditam estar acontecendo em determinado momento na organização. Dessa forma, o papel deste tipo de pesquisa é tornar claras as percepções dos funcionários sobre itens que, caso apresentem distorções indesejáveis, podem acabar afetando negativamente o nível de satisfação destes funcionários na situação de trabalho. (CODA, 1992).

Kahale conceitua pesquisa de clima organizacional como:

Um instrumento voltado para análise do ambiente a partir do levantamento de suas necessidades. Objetiva mapear ou retratar os aspectos críticos que configuram o momento motivacional dos funcionários da empresa através da apuração de seus pontos fortes, deficiências, expectativas e aspirações. (KAHALE, 2008, p. 1) 
Para Kahale (2008), a pesquisa do clima organizacional possibilita entender e conhecer melhor o comportamento humano dentro das organizações e pode ser medido através da aplicação de questionários. Sendo importante em seu fechamento, fornecer um Plano de Ação, o qual pode auxiliar a organização a efetuar diferentes ações.

Nesse sentido a Pesquisa de Clima Organizacional é uma ferramenta bastante relevante para medir o grau de satisfação e motivação dos funcionários naquele momento baseado em vários aspectos da empresa. Um clima agradável e satisfatório deve ser meta para um Gerente de Pessoas, pois significa que os funcionários estarão motivados e engajados nos objetivos e metas da organização.

Para Luz (2003) uma pesquisa de clima pode ter as seguintes variáveis: Salário, Benefícios, Segurança no Trabalho, Desenvolvimento dos Recursos Humanos, Progresso Profissional (Carreira), Integração entre os departamentos, Comunicação, Trabalho em Equipe, Valorização/ Reconhecimento, Liderança/ Gestão, Imagem da Empresa, Clareza de Objetivos, O trabalho em Si, Condições de Trabalho, Estabilidade, Processo Decisório, Condições Físicas e Disciplina.

Considerando essas variáveis, aplicar uma Pesquisa de Clima não é uma tarefa fácil, visto que os funcionários são solicitados a expor sua visão pessoal da empresa, seja ela positiva ou negativa. Saber convencer um funcionário a falar ou escrever o que pensa realmente sobre a empresa é a principal dificuldade na execução de uma Pesquisa de Clima.

Ressaltando essa dificuldade, há alguns princípios básicos para o êxito deste trabalho, o principal deles é a garantia de confidencialidade das informações. Os funcionários precisam estar seguros de que todas as informações da pesquisa são sigilosas e que não haverá qualquer retaliação sobre o que for expressado. Se isso não tiver claro, certamente os funcionários não serão sinceros em suas respostas e, sem a sinceridade, a pesquisa perde seu valor. Outra questão importante é manter a periodicidade da pesquisa: é necessário que a pesquisa não seja aplicada apenas uma vez, o ideal é avaliar anualmente o clima organizacional para manter a comparação das melhorias aplicadas no 
plano de ação da pesquisa. A formulação das perguntas também é alvo de cuidado e precisa ser considerado no momento que é decidido fazer uma pesquisa. As perguntas precisam ser de fácil entendimento para todos os níveis hierárquicos da empresa e devem ser formuladas de acordo com as características de cada empresa. Por último, o fator mais crítico concentra-se na disposição da empresa em mudar, pois não há validade em querer saber o que os colaboradores pensam se a empresa não está disposta a fazer mudanças. A pesquisa indicará quais mudanças precisam ser feitas e a empresa precisa estar preparada para todas elas.

O resultado da pesquisa identifica os itens positivos do clima organizacional que precisam ser reforçados e incentivados pela empresa e os itens críticos que precisam de melhorias. Em seguida, é desenvolvido um plano de ação efetivo voltado para o crescimento/ desenvolvimento das pessoas e da organização, sempre focado na máxima produtividade e qualidade do trabalho.

A justificativa para escolha desse tema surgiu a partir do interesse em estudar, conhecer e analisar o amplo segmento de atuação da área de Recursos Humanos na gestão de melhoria do clima organizacional. Ressaltando que o clima organizacional reflete o universo da empresa, de seus processos de trabalho, das formas de comunicação, da hierarquia praticada e, principalmente, dos tipos de pessoas que a organização atrai, o objetivo deste artigo é descrever a aplicação de uma pesquisa de clima organizacional em um clube esportivo, que teve como objetivo identificar oportunidades de melhorias na gestão dos Recursos Humanos. Convém destacar que a pesquisa de clima descrita foi aplicada somente nas áreas que compõem a Diretoria Estratégica do Clube, basicamente nos setores administrativos: Recursos Humanos, Financeiro, Contabilidade, Facilities, Jurídico, Social e Tecnologia da Informação. 


\section{Contexto e realidade investigada}

A pesquisa de clima foi aplicada em uma empresa de grande porte do ramo esportivo localizada na cidade do Rio de Janeiro/RJ que possui mais de 100 anos de existência. Por questões de sigilo profissional, o nome da empresa não será divulgado. Sua atividade fim é o futebol de campo, mas também possui forte atuação na formação de atletas em várias modalidades dos esportes olímpicos.

O estatuto que rege a organização é formado por quatro poderes: a Assembleia Geral, o Conselho Deliberativo, o Conselho Fiscal e Conselho Diretor.

Em breve resumo, a Assembleia Geral é responsável por eleger e destituir o Presidente e o Vice-Presidente Geral, bem como os membros efetivos e suplentes do Conselho Deliberativo. O Conselho Deliberativo é o órgão da manifestação dos Sócios, que detém o poder soberano, constituído por até 150 Conselheiros Natos e no mínimo 150 Conselheiros Eleitos, dentre todas as competências, é responsável por discutir e votar o Orçamento Anual e homologar a indicação de candidatos a membros do Conselho Diretor. O Conselho Fiscal tem como atividade principal examinar mensalmente o Balancete Orçamentário. Ao Conselho Diretor compete dirigir o clube e nomear os diretores dos diversos departamentos.

No estatuto está prevista a eleição do novo presidente a cada 3 anos, podendo o mesmo ter somente dois mandatos. Por se tratar de clube esportivo, toda as decisões dos Conselheiros, estão voltadas exclusivamente para a atividade principal, sendo necessário fazê-los compreender que, além de clube esportivo, a organização é uma empresa, devendo assim ter seus setores bem definidos e geridos. Cabe ao presidente e aos membros do Conselho Diretor conseguir a aprovação dos Conselheiros para questões críticas relacionadas ao dia a dia dos colaboradores. 
Em 2016, no último ano de mantado, o presidente em conjunto com a diretoria geral do clube, finalmente aprovou a criação da almejada área de Recursos Humanos, inicialmente concebida como departamento de pessoal e pertencente ao setor da Contabilidade. Foi um marco para a organização, pois o presidente acreditava que isso era um ponto importante que faltava para que sua gestão fosse completa. Já há quase 6 anos em atuação na direção do clube, seu mantado estava próximo do fim.

Para estruturar a nova área de Recursos Humanos foi necessário contratar uma Gerente de Pessoas que ficaria responsável não somente pelo $\mathrm{RH}$ mas também pelo DP. Essa gerente contratou uma profissional especializada em desenho de processos para garantir a eficaz estruturação da área. Após 4 meses de atuação, a profissional havia terminado o desenho dos processos e a divulgação a todos os funcionários estava atuante e entendida. Em seguida a divulgação, os funcionários já estavam mais familiarizados com a nova gestão de Recursos Humanos, entendendo que a área agora não era somente DP.

Agora que os processos estavam definidos e bem orientados, chegou o momento de a área de Recursos Humanos mostrar de fato sua atuação, foi, então, o momento propício para realização de uma pesquisa de clima organizacional. Seu principal desejo era que o novo presidente eleito fosse convencido da importância dessa área para a organização, para a diretoria e, principalmente, para o dia a dia dos colaboradores. A impressão era de que os colaboradores estavam "carentes" de atenção direcionada aos problemas de rotina e que precisavam de um departamento exclusivo para cuidar dessas dificuldades com a imparcialidade possível para cada momento, propondo ações que fossem de comum acordo entre funcionários e empresa.

Foi então que a nova Gerente de $\mathrm{RH}$ apresentou a proposta à diretoria do Clube defendendo a ideia de que o principal interesse era saber o que a recém-criada área de Recursos Humanos poderia identificar de melhorias no clima organizacional da empresa.

Aprovada pela diretoria, por ser uma espécie de experimento, a proposta foi que em relação aos seus fins seria uma pesquisa exploratória 
utilizando o método quantitativo em virtude de o questionário ter a maioria de suas questões fechadas, aplicada somente nas áreas que compõem a Diretoria Estratégica do Clube, basicamente nos setores administrativos: Recursos Humanos, Financeiro, Contabilidade, Facilities, Jurídico, Social e Tecnologia da Informação, e assim foi feito. 


\section{Diagnóstico da situação problema e oportunidade}

\subsection{Aprovação da Diretoria}

O processo de realização da pesquisa não foi fácil, principalmente porque a ideia da área de Recursos Humanos era algo novo para os colaboradores. Além disso, a estrutura atual de funcionários da área era muito voltada ao Departamento de Pessoal e os funcionários estavam começando a conhecer uma nova atuação da área, principalmente depois do desenho dos processos e divulgação dos mesmos.

Incialmente foi realizada uma apresentação à diretoria com as diretrizes da aplicação da pesquisa. A gerente da área ficou responsável por apresentar e defender o projeto junto ao comitê estratégico e conseguir a aprovação necessária, principalmente em relação ao respeito aos princípios básicos para aplicação de uma pesquisa de clima. Era necessário que os Diretores e Presidente fossem convencidos que ao final da pesquisa seria mister realizar mudanças, caso contrário de nada valeria a aplicação. Além disso, pela atual situação financeira do clube, era o $\mathrm{RH}$ quem iria manter a confidencialidade das informações e a periodicidade da pesquisa sem a contratação de empresa especializada. Para a Diretoria foi difícil aceitar que uma área recém-criada com uma Gestora nova na empresa tivesse toda essa autonomia, porém, foi possível convencê-los informando que o objetivo da pesquisa era o de sugerir um modelo de intervenção no clima da organização, tratando as variáveis que $o$ afetam positiva e negativamente, visando a melhoria contínua do ambiente de trabalho, da qualidade de vida no trabalho, o aumento da motivação e do comprometimento dos empregados com os resultados da empresa. 


\subsection{Planejamento da Pesquisa}

Aprovada a pesquisa, o planejamento foi realizado de acordo com Santos (2012) apresentando os tópicos: condução da pesquisa, definição das variáreis organizacionais, cronograma, preparação das chefias, divulgação aos colaboradores, aplicação e coleta dos dados, tabulação de dados, relatório final e definição do plano de ação.

Para conduzir a pesquisa, haja vista a impossibilidade de contratar uma empresa imparcial especializada no assunto, a área de Recursos Humanos definiu que somente duas pessoas seriam responsáveis por conduzir todo o processo e somente elas teriam acesso aos resultados individuais da pesquisa, mantendo assim a confidencialidade das informações, além da autonomia em todas as etapas conduzidas. As pessoas responsáveis foram a Gerente de Pessoas e a profissional que sugeriu a aplicação da pesquisa. O público alvo foi o conjunto de funcionários celetistas das áreas que compõem a Diretoria Estratégica do Clube (no total de 300 funcionários), a abrangência atingiria os funcionários das 2 sedes do clube. Segundo Santos (2012), para garantir um resultado sincero e favorável, é necessário atingir no mínimo 80\% desse público e esse foi o objetivo estabelecido.

$\mathrm{Na}$ tentativa de tornar a pesquisa algo bem cultural da empresa, foi sugerido que a campanha tivesse um nome, para que toda vez que o funcionário ouvisse ou lesse o nome soubesse que se tratava da pesquisa clima. Isso torna o processo mais intimista e de fácil memorização, ativando sensores de lembrança relativos ao tema. Para essa pesquisa os Diretores foram convidados a sugerir e definir o nome, era essencial que eles se sentissem parte integrante de todo o processo. O nome escolhido foi FALA, xxx (em que "x" é o apelido da empresa no mercado).

Por se tratar da primeira pesquisa de clima organizacional, as variáveis utilizadas na elaboração do questionário modelo foram definidas de modo a contemplar o máximo de questões relacionadas aos diferentes aspectos que possam causar insatisfação. Sendo assim, o RH definiu que, dentre as várias possibilidades, as principais consideradas para 
elaborar o questionário foram: qualificações gerais, saúde, convivência familiar, férias e lazer, autonomia, responsabilidade, realização profissional, quantidade e qualidade de trabalho, comunicação, remuneração, carreira, relacionamento com a chefia, relacionamento interpessoal, valorização profissional, treinamento e desenvolvimento, estabilidade no emprego, condições físicas de trabalho, imagem da empresa e trabalho em equipe.

A escolha das perguntas do questionário foi através de uma seleção de vários questionários padrão disponíveis na internet. Depois que foram definidas as variáveis, o $\mathrm{RH}$ buscou nos questionários questões alinhadas à realidade de trabalho das pessoas do clube e montou o questionário final. Por se tratar da primeira pesquisa de clima aplicada, o questionário ficou extenso, contendo 62 questões de múltipla escolha. Para ter uma melhor adesão dos respondentes, foi definido que a aplicação seria com o questionário físico. Assim, as pessoas foram acolhidas pelo $\mathrm{RH}$ para evidenciar a questão da confidencialidade das informações e esclarecer dúvidas.

O cronograma foi muito curto, pois o mandato do presidente acabaria em um mês e os resultados finais precisavam ser avaliados e apresentados até sua saída, essa foi uma condição imposta na aprovação da pesquisa. Todas as etapas da pesquisa ocorreram no período de 15 de outubro a 21 de novembro de 2016. Apesar do curto tempo, era importante que todas as etapas da pesquisa fossem respeitadas.

Foi extremamente relevante a realização de uma conversa com os gestores de cada área dos respondentes da pesquisa, para que eles soubessem como uma pesquisa é realizada e ajudassem a área de Recursos Humanos a atingir o máximo de pessoas possíveis em cada área, porém, a intensão principal era que eles estivessem preparados para possíveis críticas a que seriam expostos. A principal ideia era que todas as críticas fossem vistas como construtivas, que a área de Recursos Humanos estava realmente levantando todos os aspectos possíveis de insatisfação para trabalhar no plano de ação junto aos gestores e mudar o cenário atual, tornando o ambiente de trabalho mais harmonioso e cooperativo. Na conversa todos os gestores receberam 
muito bem a intensão do $\mathrm{RH}$ com a pesquisa, elogiaram a iniciativa e estavam apreensivos com os possíveis resultados. Surgiram algumas dúvidas referentes a possíveis demissões após a aplicação da pesquisa, mas o RH deixou claro que isso não ocorreria, que a ideia era melhorar o sistema de gestão e torná-los lideres melhores.

\subsection{Divulgação da Pesquisa}

Com os gestores cientes do que iria acontecer, foi feito o planejamento da divulgação aos funcionários. Os textos da divulgação foram baseados em vários artigos e comentários facilmente encontrados na internet, alguns deles adaptado à realidade do clube. Essa divulgação foi feita por e-mail e com cartazes nos murais da empresa com intervalo de dois dias cada uma. Dividida em quatro comunicados:

- O que é Pesquisa de Clima? - Muitos dos funcionários do clube são colaboradores há mais de 10 anos e alguns não passaram por outras empresas onde pudessem ter vivenciado esse tipo de pesquisa, então a razão principal desse comunicado foi explicar aos funcionários exatamente o que é uma pesquisa de clima e quais as etapas envolvidas, através de um texto simples e com fácil entendimento (vide anexo 1).

- Qual a importância e o objetivo do clube? - Era fundamental que os colaboradores soubessem a importância de uma pesquisa desse porte e qual o objetivo dela para a empresa e não tivessem receio de respondê-la e respondesse da forma mais sincera possível (vide anexo 2).

- Como será a pesquisa? - Esse comunicado explicou detalhadamente como a pesquisa seria aplicada com todas as regras bem definidas e alinhadas. A intensão é que todo processo fosse o mais transparente possível, evidenciando a credibilidade que a área de Recursos Humanos queria como imagem de atuação profissional (vide anexo 3). 
- Convite para participação - Foi importante fazer com que os funcionários embarcassem juntos nesse processo e se sentissem parte de toda essa mudança. Sendo assim, foi feito um convite formal para participação de todos (vide anexo 4).

\subsection{Aplicação da Pesquisa e Tabulação dos Dados}

A aplicação da pesquisa foi realizada em espaço neutro e de fácil acesso a todos os colaboradores durante dois dias inteiros de trabalho em ambas as sedes do Clube, pois o clube trabalha com algumas escalas de revezamento e era valoroso que todos tivessem a oportunidade de responder. Era necessário que eles estivessem confortáveis para responder e não se sentissem coagidos. As colaboradoras do Recursos Humanos responsáveis pela aplicação da pesquisa estavam presentes para qualquer dúvida e para manter o sigilo e anonimato de todos os respondentes. Foi disponibilizado uma urna lacrada onde os questionários eram depositados em ordem aleatória.

No questionário foi utilizada uma folha de introdução (anexo 5) ao preenchimento da ficha de pesquisa principal (anexo 6) com 62 perguntas e respostas na opção múltipla escolha e da folha avulsa (anexo 7). A ficha principal permitiu fazer o levantamento dos fatores internos e externos que influenciam os colaboradores e qual o nível atual que se encontravam, nela estavam contidas todas as perguntas para avaliar as variáveis definidas. A folha avulsa permitiu ao colaborador que relatasse suas observações e/ou comentários sobre sua opção em alguns dos itens da pesquisa, expor suas críticas, elogios ou sugestões referentes a suas atividades, a empresa, aos seus pares, superiores ou subordinados, ou a qualquer outro item que desejasse.

É claro que como tudo que é novo, a adesão para responder a pesquisa foi um pouco demorada, principalmente na sede principal do Clube. Algumas pessoas ainda estavam receosas em responder, sendo preciso um empenho maior da área de Recursos Humanos para visitar cada setor e reforçar a importância da pesquisa, o que poderia trazer de 
melhorias para a empresa no todo e para cada um individualmente. Com isso, algumas pessoas responderam no próprio setor de trabalho. Neste momento foram observados comentários como: "estão marcando a ordem dos questionários, vão saber que é a gente", "não posso falar mal do meu chefe porque vão logo saber que sou eu, serei demitido", "não vejo porque fazer isso agora, nada aqui tem jeito de melhorar", e outros comentários similares. Nessa hora foi necessário ter calma e convicção de todo trabalho que estava sendo realizado e repassar a esses funcionários a credibilidade da pesquisa e de quem a estava aplicando. $O$ principal era fazê-los compreender que aquilo era para melhorar a qualidade de vida deles no trabalho, e essa foi a principal dificuldade nessa Sede.

$\mathrm{Na}$ outra sede do clube a adesão foi mais fácil, o gestor da sede foi muito parceiro do $\mathrm{RH}$ na divulgação da importância da pesquisa, principalmente porque nessa sede não tinha ninguém efetivo do $\mathrm{RH}$ que pudesse ajudar na divulgação aos funcionários. Ele reforçou efetivamente que aquele era $o$ instrumento para que todos os problemas apontados a ele no dia-a-dia de fato ficassem registrados e pudessem ter uma resolução mais efetiva. Além de captar a essência da pesquisa e levar isso para o cotidiano da sede e para os funcionários da sede de forma clara e possível. Isso foi essencial para o $\mathrm{RH}$ se aproximar da meta estabelecida de atingir $80 \%$ dos funcionários.

Toda tabulação dos dados foi realizada pelas pessoas responsáveis pela pesquisa dentro da área de Recursos Humanos, em sala privada, mantendo sempre o sigilo aos demais departamentos e colaboradores. Nenhum material utilizado na coleta de dados foi disponibilizado à diretoria ou aos demais gestores. O levantamento dos dados foi bem trabalhoso em função dos questionários físicos, tendo sido necessária muita atenção para evitar erros na contagem de cada questão. Essa foi a parte mais demorada de toda a pesquisa, levando dias para sua conclusão.

Levantados todos os dados, quantificados e graficamente representados, no relatório final foi considerado somente os pontos relevantes da pesquisa, aqueles que analisados pela área de Recursos 
Humanos, foram considerados avaliados muito positivamente e muito negativamente, estes mereciam atenção especial e plano de ação adequado.

A avaliação do RH considerou um percentual aceitável para cada variável definida na elaboração da pesquisa com base na experiência das duas profissionais da área responsáveis pela pesquisa e na análise de literatura do tema. 


\section{Análise da situação e proposta de solução}

\subsection{Panorama Geral}

Encerrada a coleta e tabulação dos dados obtidos, iniciou-se a análise dos resultados. Nessa fase vale ressaltar alguns dos ensinamentos obtidos durante a aplicação da pesquisa: os dados obtidos na folha avulsa devem ser analisados e confrontados com os dados da ficha principal, pois os dados levantados da ficha avulsa ajudam a explicar, esclarecer ou reforçar os resultados obtidos na ficha de pesquisa principal, sobretudo quando se trata de algum resultado negativo. Além disso, foi notável que os funcionários insatisfeitos tiveram mais disposição em se manifestar, utilizando-se de todas as formas possíveis.

Os dados apontados no questionário por completo (ficha principal e folha avulsa), permitiram realizar o levantamento dos pontos relevantes referentes ao relacionamento entre funcionário e empresa, identificando os problemas já existentes e os que estão com indícios de ocorrer.

A pesquisa teve sua meta de participação atingida, dos 300 funcionários ativos nas aréas de aplicação no clube, houve 249 respondentes, ou seja $83 \%$ do total, sendo 161 da sede principal e 87 da segunda sede. A seguir panorama geral dos respondentes: 


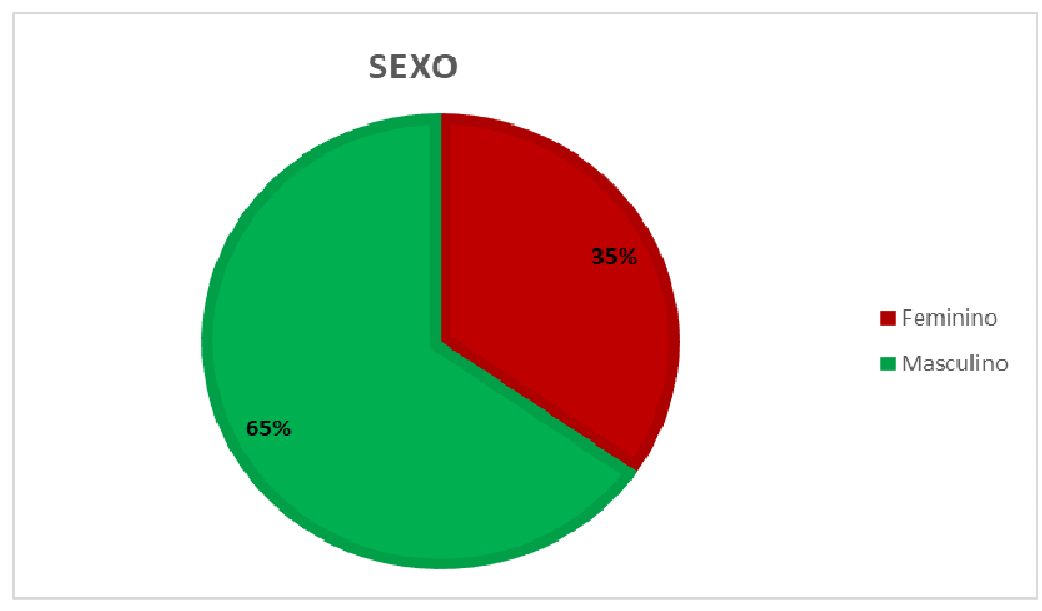

Figura 1: Gráfico do gênero dos respondentes.

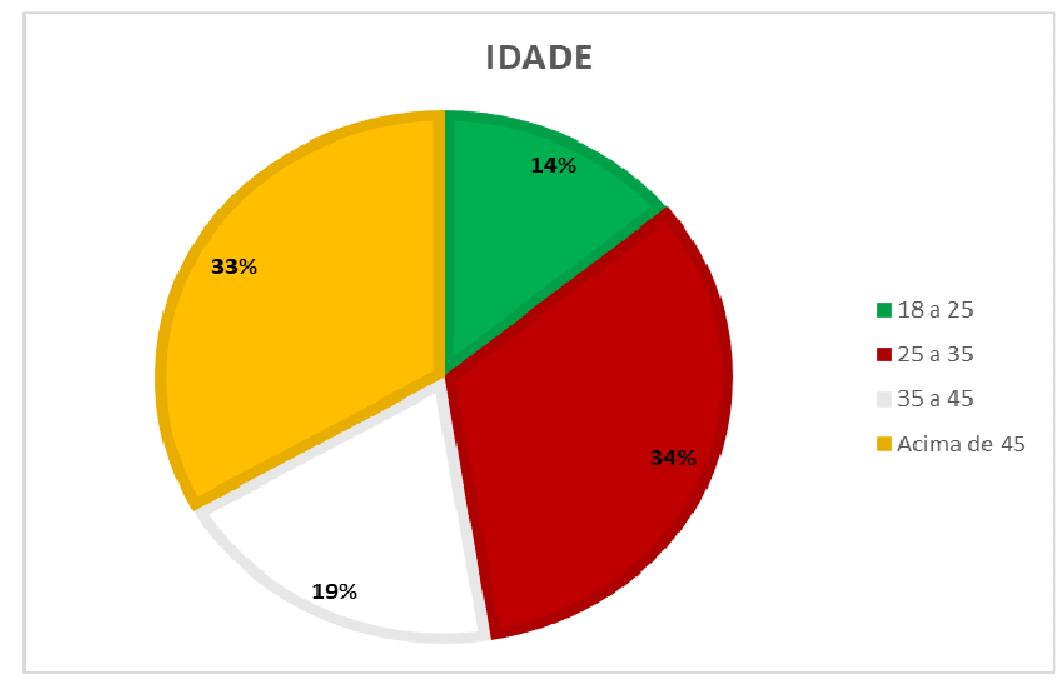

Figura 2: Gráfico com a idade dos respondentes em anos.

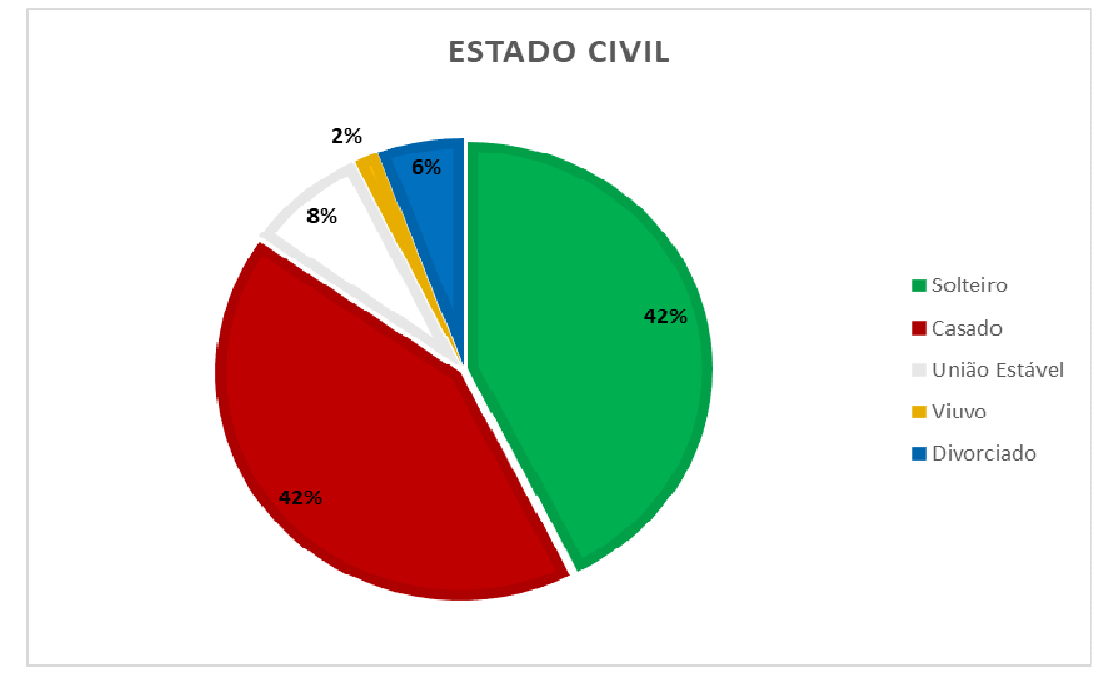

Figura 3: Gráfico do estado civil dos respondentes. 


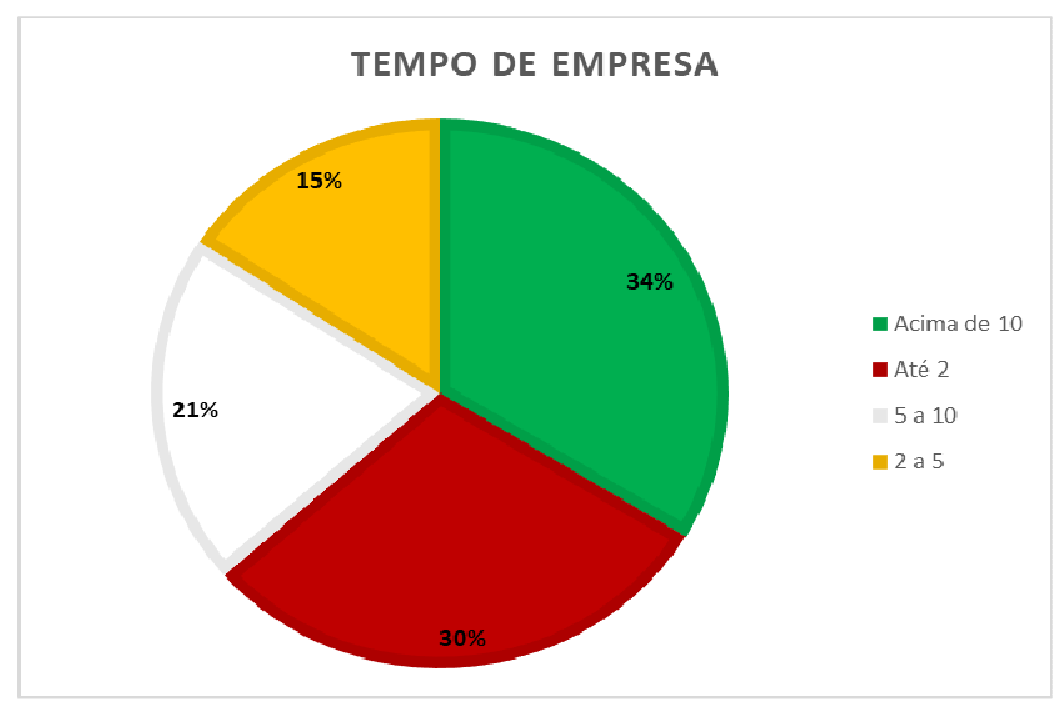

Figura 4: Gráfico com o tempo de empresa dos respondentes em anos.

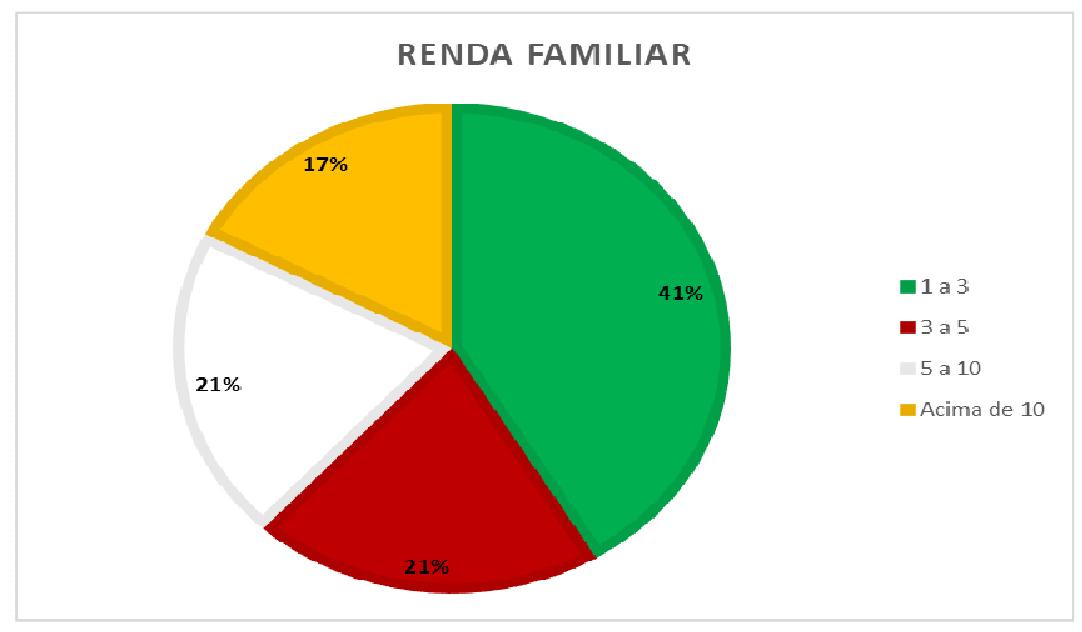

Figura 5: Gráfico com a renda familiar dos respondentes em salários mínimos (novembro,2016).

\subsection{Análise dos Pontos Relevantes e Plano de Ação}

Para mapear os problemas, no momento de definição das variáveis que seriam avaliadas na pesquisa, a diretoria do clube, utilizando como base o estudo realizado por D'Otaviano (2009) considerou os seguintes percentuais satisfatórios para cada variável apresentada: 


\begin{tabular}{|lc|}
\hline \multicolumn{1}{|c|}{ Variável Analisada } & Índice Satisfatório para respostas positivas \\
\hline Férias e Lazer & $95 \%$ \\
Autonomia & $80 \%$ \\
Responsabilidade & $80 \%$ \\
Realização Profissional & $90 \%$ \\
Quantidade e Qualidade de Trabalho & $70 \%$ \\
Comunicação & $80 \%$ \\
Remuneração & $70 \%$ \\
Carreira & $75 \%$ \\
Relacionamento com a Chefia & $95 \%$ \\
Relacionamento Interpessoal & $90 \%$ \\
Valorização Profissional & $95 \%$ \\
Treinamento e Desenvolvimento & $75 \%$ \\
Estabilidade no Emprego & $95 \%$ \\
Condições Físicas de Trabalho & $90 \%$ \\
Imagem da Empresa & $90 \%$ \\
Trabalho em Equipe. & $90 \%$ \\
\hline
\end{tabular}

Tabela 1: Percentual definido como "Satisfatório" para cada variável avaliada.

Por se tratar da primeira pesquisa aplicada na empresa, os percentuais estabelecidos com base em D'Otaviano (2009), considerou o melhor cenário possível para cada variável, vislumbrando o cenário ideal para se trabalhar.

Após mapear os problemas, foi definido o plano de ação considerando os pontos mais relevantes pelo $\mathrm{RH}$ ressaltados na pesquisa: cooperação entre departamentos, opções de treinamento ofertados pela empresa, fatores principais de desmotivação e motivação, imagem da liderança, comunicação interna, condições do ambiente de trabalho e prestígio da empresa. A análise e escolha desses pontos considerou os percentuais definidos pelas profissionais de $\mathrm{RH}$ com base no tempo de carreira e experiências profissionais passadas.

O plano de ação foi elaborado seguindo o modelo de atuação PDCA (do inglês: PLAN - DO - CHECK - ACT), conhecido também com Método de Melhorias PDCA, ciclo PDCA, ciclo de Shewhart ou ciclo de Deming. Sendo ele um método gerencial que busca a melhoria contínua através de quatro passos. O método é simples e sua própria sigla nos ajuda a entende-lo: planejar, fazer, verificar e agir. 
O conceito de Método de Melhorias, conhecido como Ciclo PDCA foi originalmente desenvolvido na década de 1930, nos Laboratórios da Bell Laboratories - EUA, pelo estatístico Walter A. Shewhart, definido como um ciclo estatístico de controle dos processos que pode ser aplicado para qualquer tipo de processo ou problema.

Segundo Nascimento (2011), o Ciclo PDCA é projetado para ser usado como um modelo dinâmico. A conclusão de uma volta do ciclo irá fluir no começo do próximo ciclo, e assim sucessivamente. Seguindo no espírito de melhoria de qualidade contínua, o processo sempre pode ser reanalisado e um novo processo de mudança poderá ser iniciado.

A primeira etapa é a que será evidenciada nesse artigo. Planejar engloba definir os problemas que queremos solucionar e os objetivos que queremos alcançar, seja um problema já conhecido, alguma reclamação recorrente ou um objetivo novo, é a etapa mais importante do ciclo se não for bem executada as etapas seguintes serão comprometidas e dificilmente o resultado desejado será alcançado.

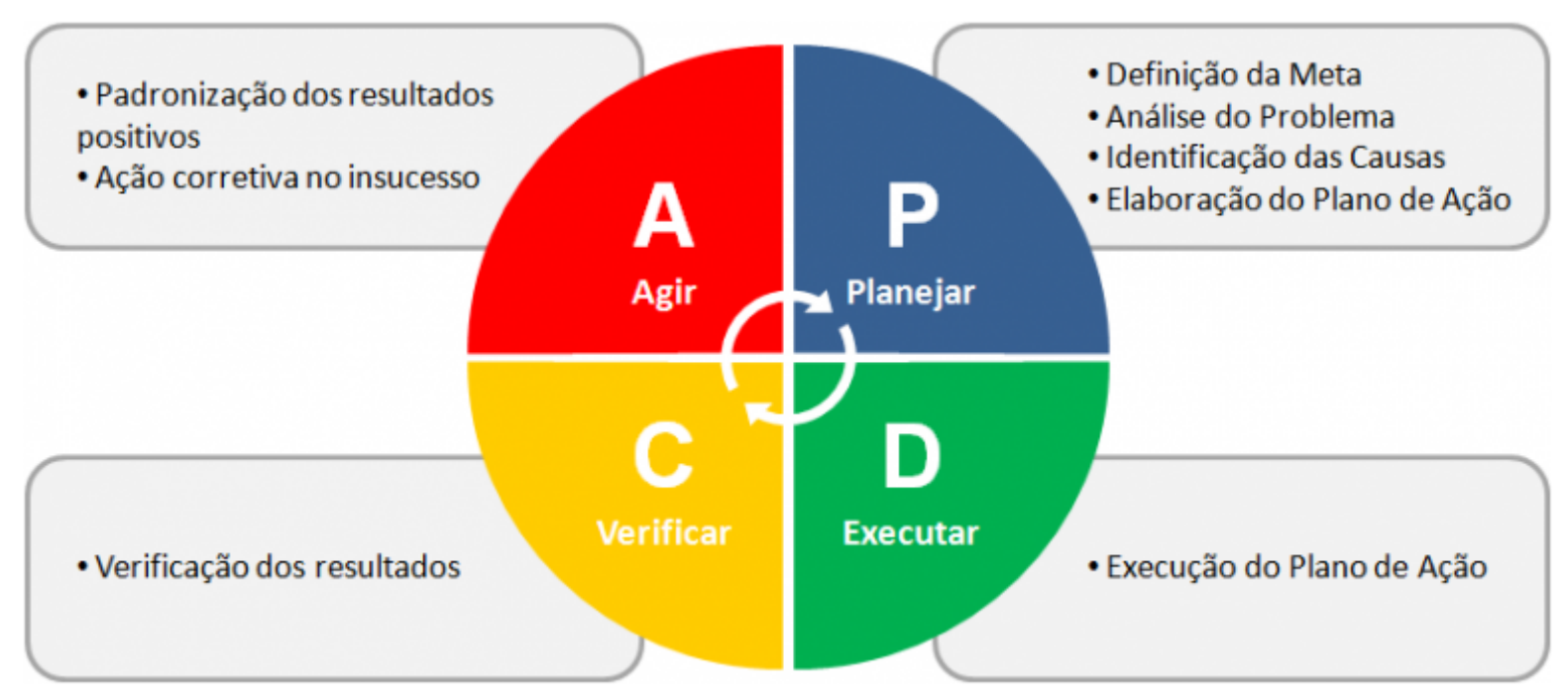

Figura 6: Modelo ilustrativo do Método PDCA

Fonte:https://vanderhulst.com.br/blog/2017/05/05/pdca-uma-ferramenta-noprocesso-de-melhoria-continua-para-a-sua-empresa/ Consulta em 10/10/2017

$\mathrm{Na}$ análise dessa pesquisa, para montar o plano de ação sugerido, além do levantamento da causa relacionada, que é o problema de fato apresentado no levantamento dos dados, foi necessário responder quatro 
questões básicas: o que fazer, como fazer, quem será o responsável e quando será executado?

A partir dessas respostas criou-se o Plano de ação definido e com metas claras. As etapas seguintes do PDCA não serão apresentadas nesse artigo. O plano de ação foi criado para ser posto em prática durante todo o ano de 2017.

A seguir as causas relacionadas, ou seja, os problemas de fato obtidos do mapeamento.

\subsubsection{Falta de Cooperação entre Departamentos}

Segundo Luz (2003) p. 23 :

"A cooperação é uma relação de ajuda entre indivíduos e/ou entidades no sentido de alcançar objetivos comuns, utilizando métodos mais ou menos consensuais".

A falta de cooperação acontece em grupos e equipes que não possuem uma estrutura e pessoas preparadas para a realização de atividades em conjunto.

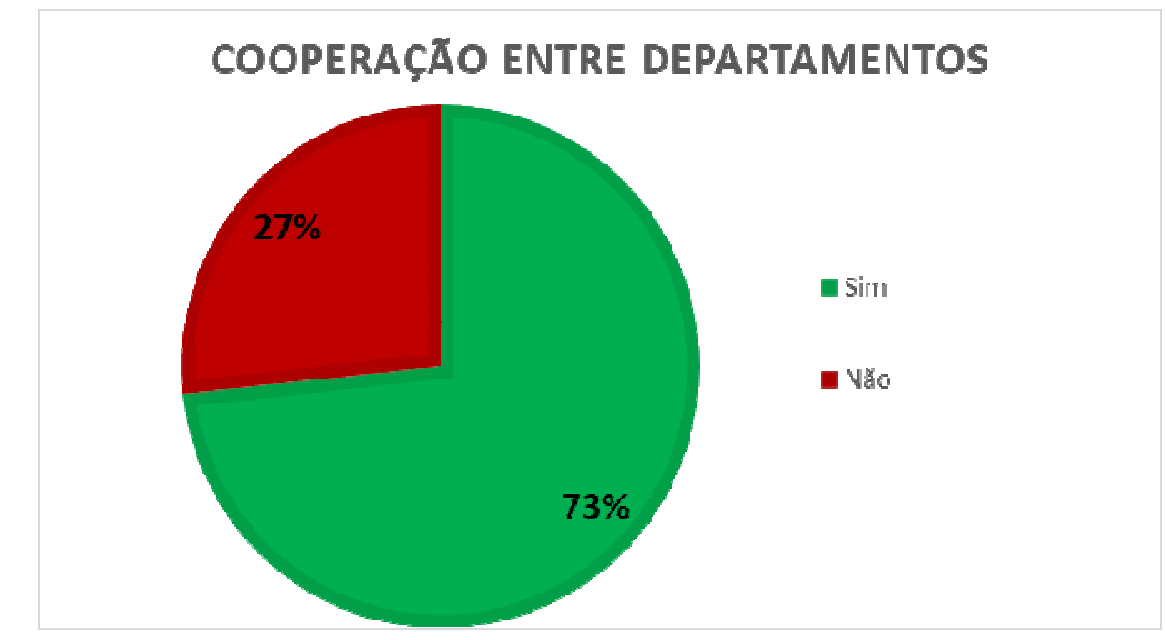

Figura 7: Gráfico da percepção dos respondentes quanto a cooperação entre departamentos.

Considerando o cenário ideal de integração e diálogo entre os departamentos e equipes parametrizado para a pesquisa como $90 \%$ 
satisfatório, o percentual alcançado de $27 \%$ dos funcionários informando que acreditam não existir cooperação entre os departamentos não atingiu a meta. Isso pode ser confirmado quando verificamos que 0 relacionamento entre os funcionários tem percentuais de índices "Razoável" e "Ruim" consideravelmente altos.

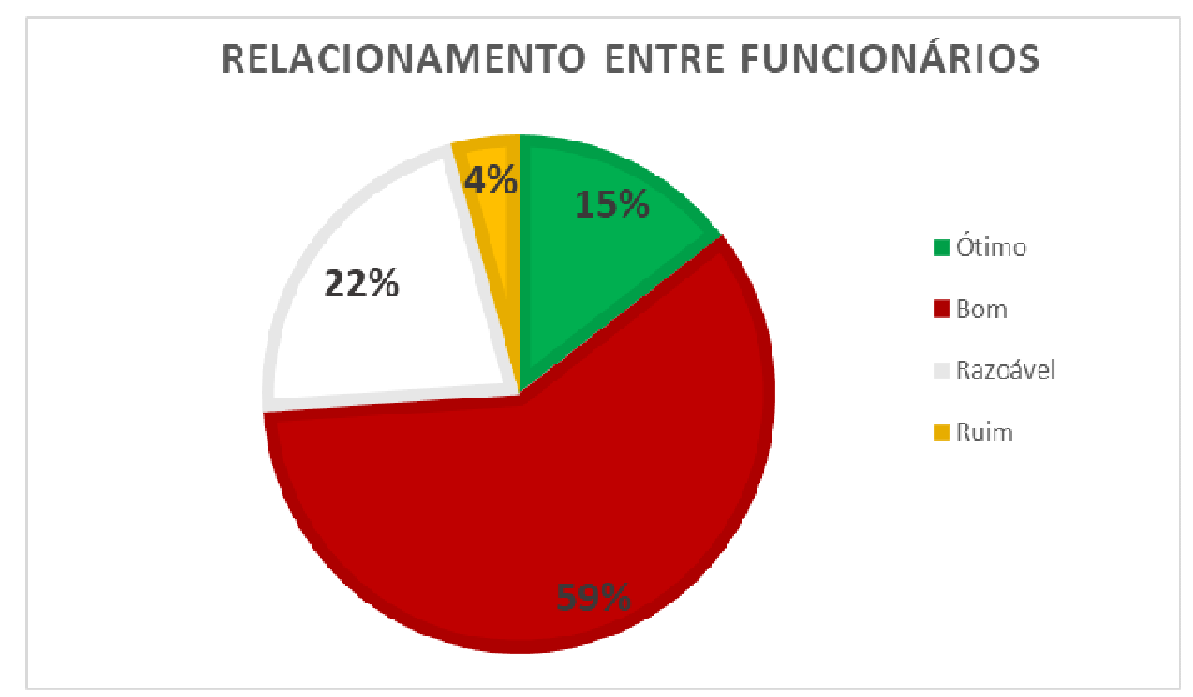

Figura 8: Gráfico da percepção dos respondentes quanto ao relacionamento entre funcionários.

Seguindo a ideia de que os funcionários precisavam interagir mais e conhecer melhor a área de atuação do outro, as implicações, normas e regras de cada departamento, chegou-se à proposição abaixo:

\section{$\mathrm{O}$ que fazer?}

Foi definido que a melhor maneira de solucionar esse problema era criando grupos de trabalho para desenhar os procedimentos de cada departamento.

\section{Como fazer?}

Reunindo representantes indicados pelos gestores de cada área envolvida no processo com a finalidade de promover maior interação, definição, esclarecimento e desenho dos processos.

\section{Quem será o responsável?}

Nessa integração entre departamentos o RH ficará responsável por formar os grupos com as indicações dos gestores para criar cada procedimento necessário às áreas de impacto no dia-a-dia. 


\section{Quando?}

A criação de todos os grupos e a definição de qual procedimento cada um iria desenhar deveria estar pronto até fevereiro/2017.

\subsubsection{Falta de Treinamento para os Funcionários}

O treinamento é um ingrediente chave para motivar pessoas, além de ser fundamental para o desenvolvimento organizacional. É proveitoso tanto para os empregadores quanto aos funcionários de uma organização. Um funcionário se torna mais eficiente e produtivo quando bem treinado.

Visando ao aprendizado contínuo dos funcionários, as metas apresentadas para a pesquisa foi de que $75 \%$ dos funcionários tivessem a percepção de que a empresa investe em treinamento e aprendizado contínuo. $O$ resultado obtido pela pesquisa evidenciou que a percepção deles é que não são oferecidos treinamentos e/ou subsídios para aperfeiçoamento profissional.

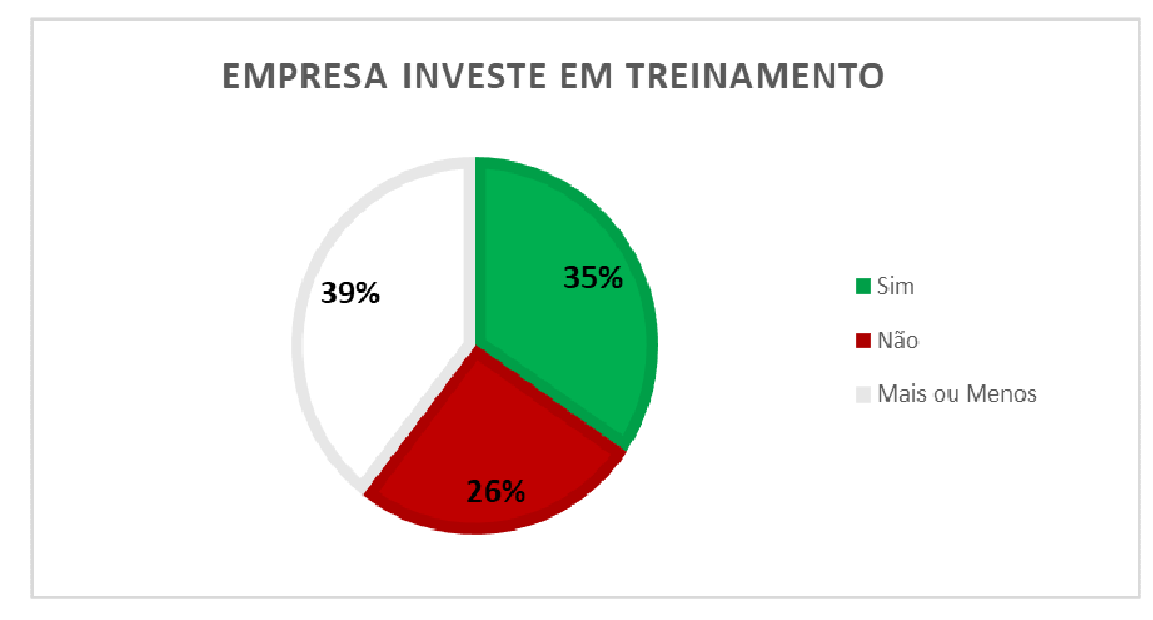

Figura 9: Gráfico da percepção dos respondentes em quanto a empresa investe em treinamento. 


\section{A EMPRESA INVESTE NO APRENDIZADO}

CONTÍNUO

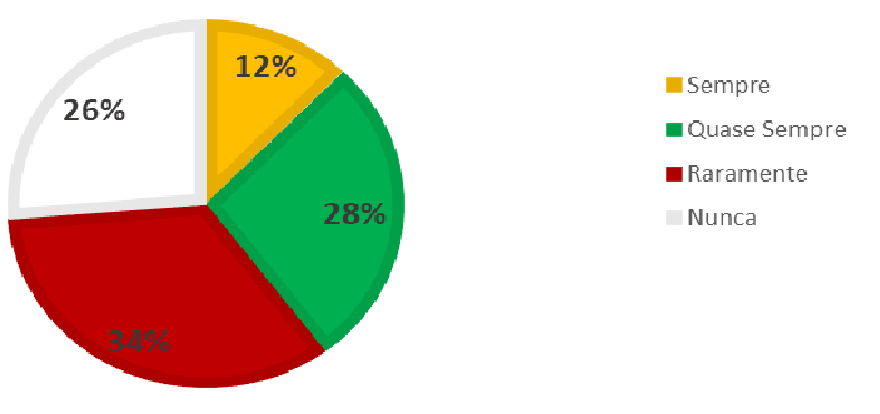

Figura 10: Gráfico da percepção dos respondentes em quanto a empresa investe no aprendizado contínuo.

Considerando o impedimento financeiro de contratar treinamentos externos para os funcionários, foi sugerida a solução abaixo:

\section{O que fazer?}

Criar centros de estudo para transmissão de informações e conhecimentos.

\section{Como fazer?}

1. Levantando as demandas de treinamento para cada área através de informação fornecida pelo gestor e;

2. Reunindo colaboradores que possuem conhecimento específico em determinados assuntos para ministrar treinamentos.

\section{Quem será o responsável?}

Todo o trabalho seria realizado pela pessoa do $\mathrm{RH}$ responsável pelo Treinamento e Desenvolvimento.

\section{Quando?}

1. Para o levantamento das demandas de treinamento o prazo estipulado foi concluir até janeiro/2017; e

2. Para a elaboração dos treinamentos, o prazo foi definido para março/2017. 


\subsubsection{Qualificação da Liderança na Gestão de Pessoas}

Muitas são as responsabilidades de um líder. Geralmente, espera-se desse profissional eficiência em dirigir uma equipe, conquistar os melhores resultados para a empresa, manter um ambiente saudável e harmonioso, além de ter o respeito de seus liderados. Um bom líder inspira desempenho.

O líder deve promover um ambiente de trabalho que preza a qualidade de vida, a valorização profissional e o desenvolvimento de carreira. É assim que deve ser definido o trabalho dele em reter os talentos da sua equipe e proporcionar um ambiente sadio e harmonioso. O líder precisa ser visto como um exemplo a ser seguido, seus subordinados precisam ter orgulho de fazer parte da sua equipe.

Nesse contexto, a empresa desejava que $95 \%$ da sua liderança fosse receptiva à mudança e tivesse um ótimo relacionamento com a equipe. No resultado, os índices negativos foram altos, considerando que os funcionários não visualizavam o gestor como um Líder. Um percentual consideravelmente alto não se sentia totalmente respeitado pelo gestor.

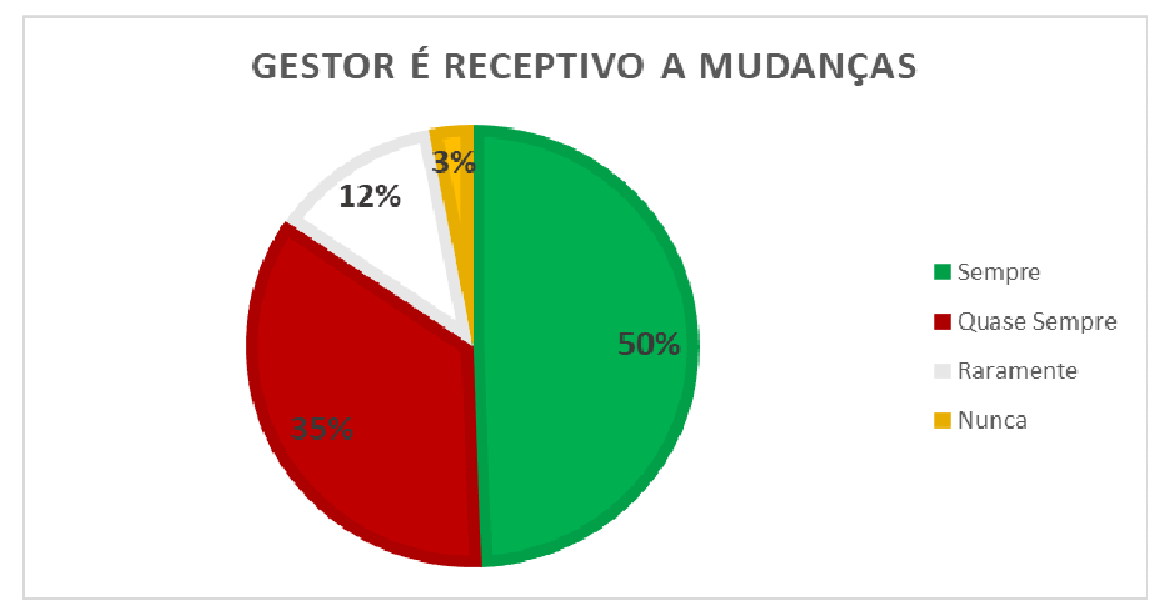

Figura 11: Gráfico da percepção dos respondentes em relação ao gestor imediato ser receptivos a mudanças. 


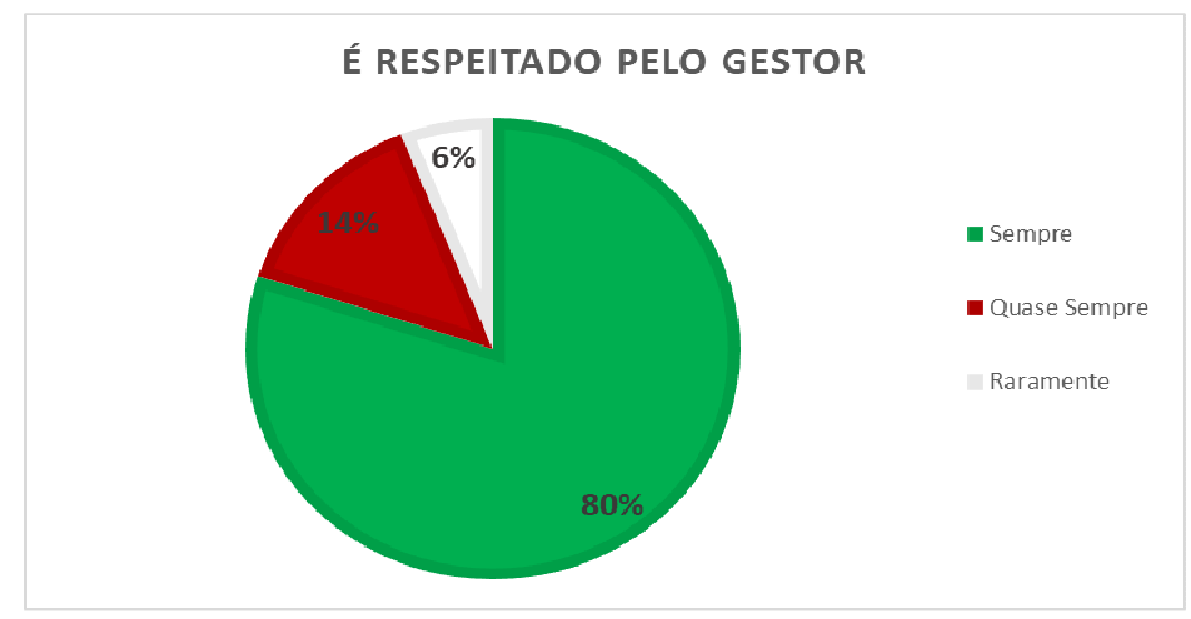

Figura 12: Gráfica da percepção dos respondentes em relação a ser respeitado pelo gestor.

Esse item foi considerado crítico, pois um funcionário para trabalhar motivado precisa ter uma liderança atuante e receptiva. Foram propostas 6 soluções de melhoria:

\section{0 que fazer?}

1. Oferecer treinamento aos gestores;

2. Promover palestras sobre liderança;

3. Promover feedbacks mais constantes (gestor $x$ funcionário $x$ gestor);

4. Criar organograma estruturado de cada departamento;

5. Promover autonomia das áreas; $\mathrm{e}$

6. Realizar avaliação de desempenho.

\section{Como fazer?}

1. Promovendo encontros entre gestores para discurssão de melhores práticas em relação a gestão de pessoas (mesa redonda);

2. Convocando uma palestra para discurssão do tema;

3. Definindo novo procedimento para feedback (4 em 4 meses);

4. Definindo quem são os gestores e convocando-os a alinharem sua área;

5. Convidando so gestores a assumirem as responsabilidades e autonomia de decisões da sua área; e 
6. Definindo superiores, pares e subordinados para avaliação anônima do gestor.

\section{Quem será o responsável?}

1. Recursos Humanos com o conceito de "mesa redonda" onde não existe o certo e o errado, existe 0 mais adequado para cada situação;

2. Treinamento e Desenvolvimento buscando melhor custo;

3. Treinamento e Desenvolvimento definindo o método que será utilizado;

4. Recursos Humanos junto à Diretoria Geral do Clube;

5. CEO do Clube, sendo ele responsável principal por promover; e

6. Treinamento e Desenvolvimento definirá o melhor método.

\section{Quando?}

1. Janeiro/2017;

2. Fevereiro/2017;

3. Maio/2017;

4. Dezembro/2016;

5. Janeiro/2017; e

6. Junho/2017.

\subsubsection{Falta de Comunicação Interna}

A comunicação interna é o gerenciamento estratégico da circulação de informações dentro da empresa que objetiva motivar, integrar e engajar os públicos internos (lideranças, colaboradores, prestadores de serviço, terceirizados, funcionários autônomos, trainees, estagiários, familiares, entre outros) aos objetivos do negócio.

Visando a melhor integração entre os funcionários e empresa, é considerado que a comunicação precisa sempre ser clara, efetiva e ao alcance de todos. Quase metade dos funcionários respondentes consideraram a comunicação interna "Razoável" ou "Ruim", isso indica que a informação que a empresa desejava repassar não estava atingindo todo o público de colaboradores. Essa questão ficou evidenciada quando 
um percentual consideravelmente alto entende que a empresa não tinha um canal (comunicação / liderança) para receber e entender as críticas.

\section{COMUNICAÇÃO INTERNA}

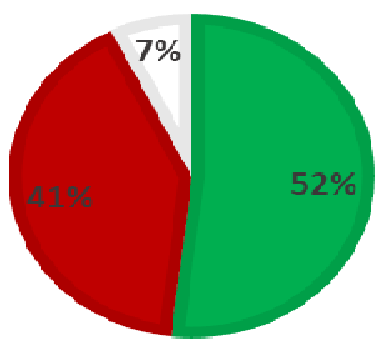

- Adequado

- Razoável

Inade quado

Figura 13: Gráfico da percepção dos respondentes quanto a comunicação interna.

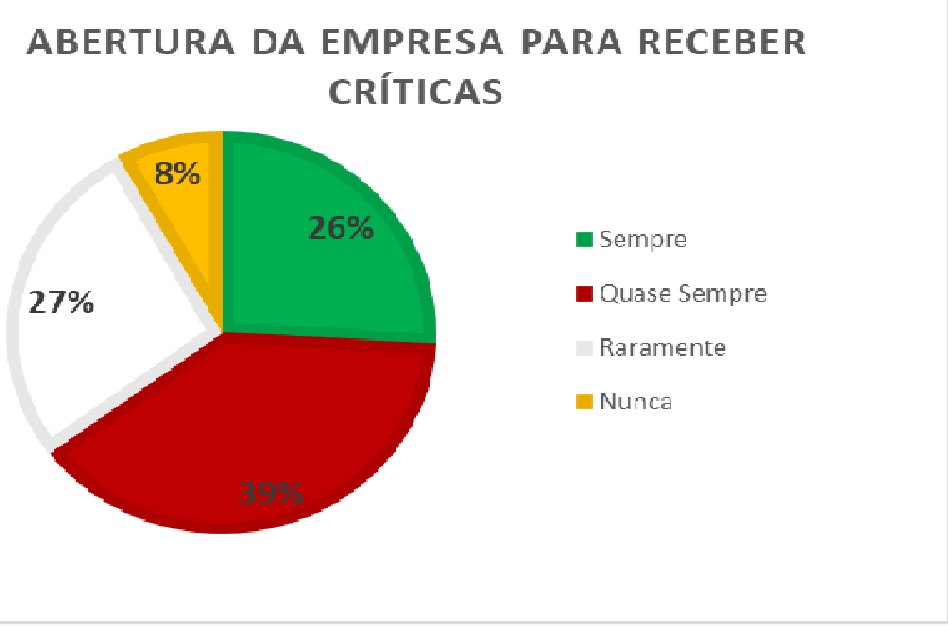

Figura 14: Gráfico da percepção dos respondentes referente a abertura da empresa para receber críticas.

Nesse item, foi essencial entender qual seria o melhor canal de comunicação da empresa com os funcionários, desse modo foi proposto a melhoria a seguir:

\section{O que fazer?}

1. Implementar Intranet; e

2. Implementar programa de integração. 


\section{Como fazer?}

1. Definindo sistema utilizado, modo de divulgação e controle; e

2. Criando programa de recrutamento interno e criando programa de Boas Vindas - Admissão.

\section{Quem será o responsável?}

1. Comunicação e TI; e

2. Recursos Humanos.

\section{Quando?}

1. Março/2017; e

2. Março/2017.

\subsubsection{Falta de Ferramentas de Trabalho}

As condições ambientais de trabalho devem estar adequadas aos trabalhadores e a natureza do trabalho que eles executam. Quando eles estão atuando em condições ambientais desfavoráveis, sua entrega não será total ao empenho da função. A qualidade no ambiente de trabalho visa facilitar e satisfazer as necessidades do trabalhador ao desenvolver suas atividades na organização.

Visando a proporcionar o melhor ambiente físico possível, a meta estabelecida era que todas as condições ambientais tivessem no máximo $10 \%$ de funcionários insatisfeitos.

Após o mapeamento de cada ponto avaliado negativamente, considerando o método PDCA, o $\mathrm{RH}$ propôs os planos de ação relacionando a causa com o que deve ser feito, como deve ser feito, por quem e em que prazo iniciar. 


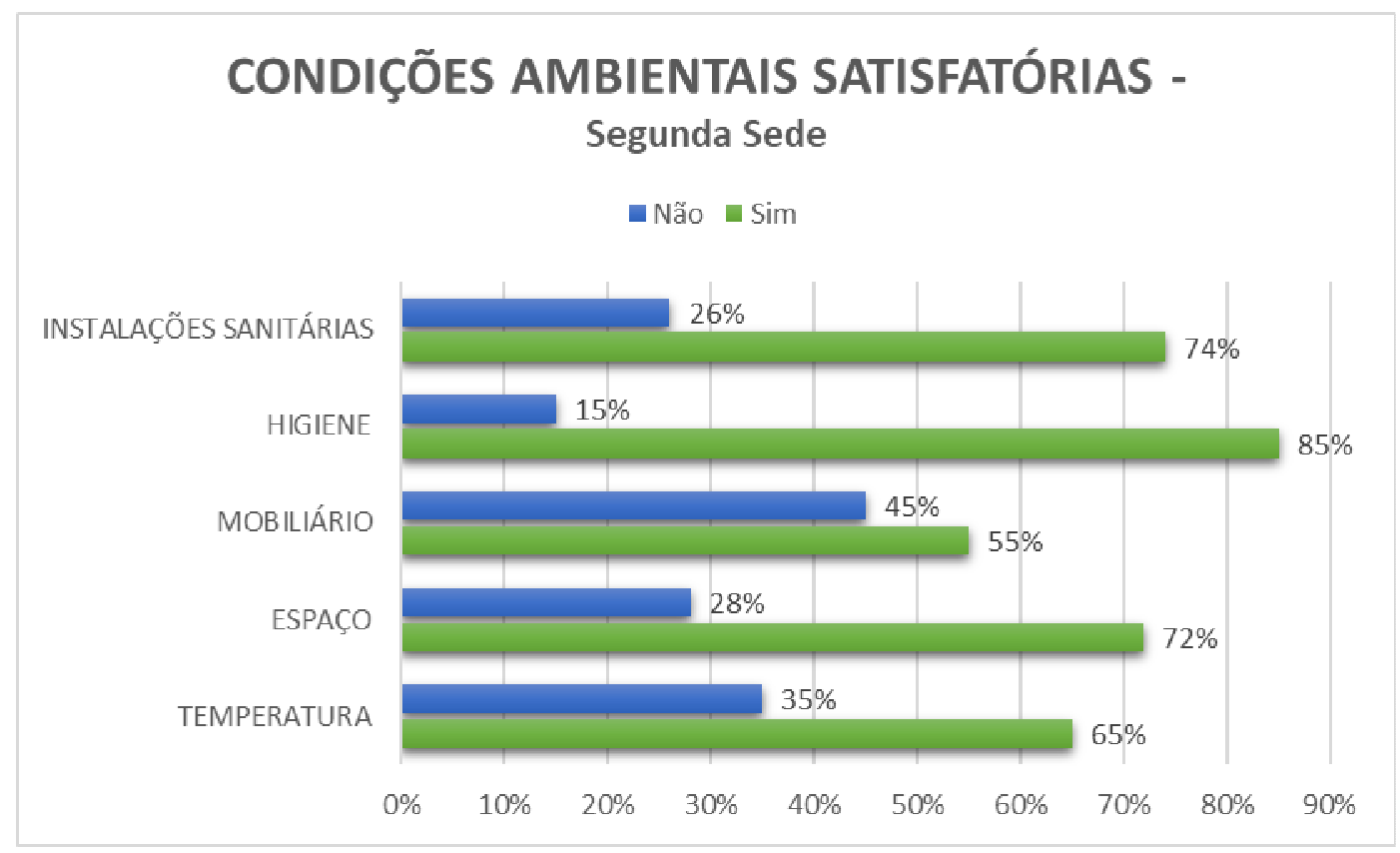

Figura 15: Gráfico da percepção dos respondentes da segunda sede em relação as condições ambientais de trabalho.

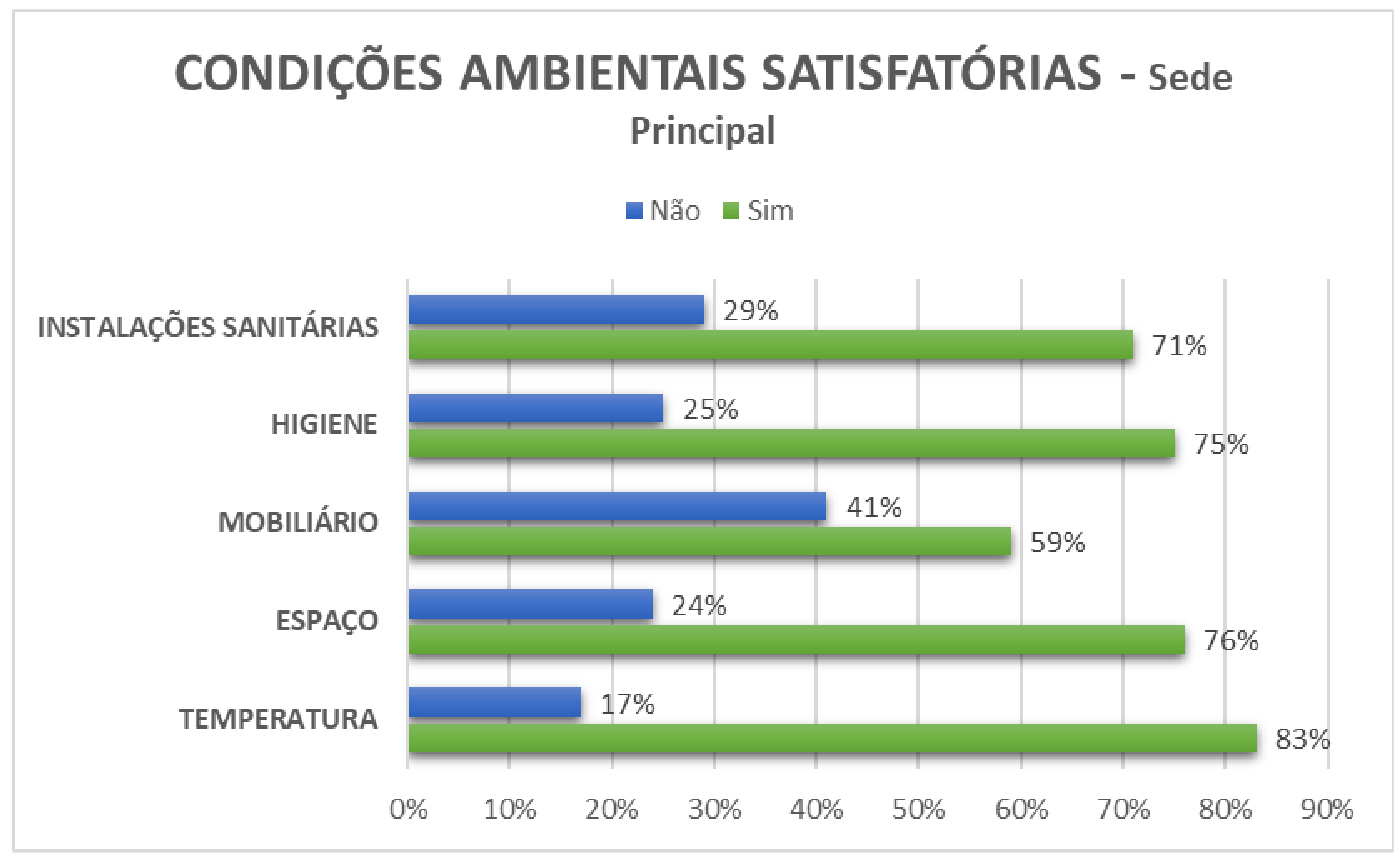

Figura 16: Gráfico da percepção dos respondentes da sede principal em relação as condições ambientais de trabalho. 
Apesar desse item ser discriminado entre as duas sedes, o plano de ação proposto para ambas foi o mesmo, a seguir:

\section{0 que fazer?}

1. Implementar acesso a internet adequado;

2. Melhorar materiais e instalações;

3. Melhorar instalações sanitárias; e

4. Melhorar mobiliário.

\section{Como fazer?}

1. Disponibilizando WIFI gratuitamente para todos os funcionários;

2. Levantamento dos materiais críticos para execução das tarefas;

3. Levantamento de pontos críticos e obras em banheiros e vestiários; e

4. Trocando itens críticos.

\section{Quem será o responsável?}

1. $\mathrm{Tl}$;

2. Treinamento e Desenvolvimento;

3. Facilities; e

4. Facilities.

\section{Quando?}

1. Março/2017;

2. Janeiro/2017;

3. Fevereiro/2017; e

4. Fevereiro/2017.

\subsubsection{Fatores de Desmotivação}

A desmotivação profissional é causada por diversos fatores decorrentes da rotina diária de um profissional. O acúmulo de tarefas, obrigações e as cobranças geradas por um mercado cada vez mais competitivo e exigente acabam gerando a tão indesejada desmotivação.

A desmotivação surge quando algo começa a incomodar o profissional e, muitas vezes, torna-se constante e acaba exercendo 
influência sobre o seu rendimento, desanimando-o e o tornando improdutivo. As insatisfações variam de acordo com cada indivíduo, têm intensidades diferentes, mas normalmente são oriundas de divergências pessoais ou profissionais.

A análise do item abaixo não precisou de percentual estabelecido pois a pergunta era bem objetiva ao resultado. Apesar dos gráficos das sedes serem distintos, basicamente os principais fatores de desmotivação são os mesmos conforme observado abaixo:

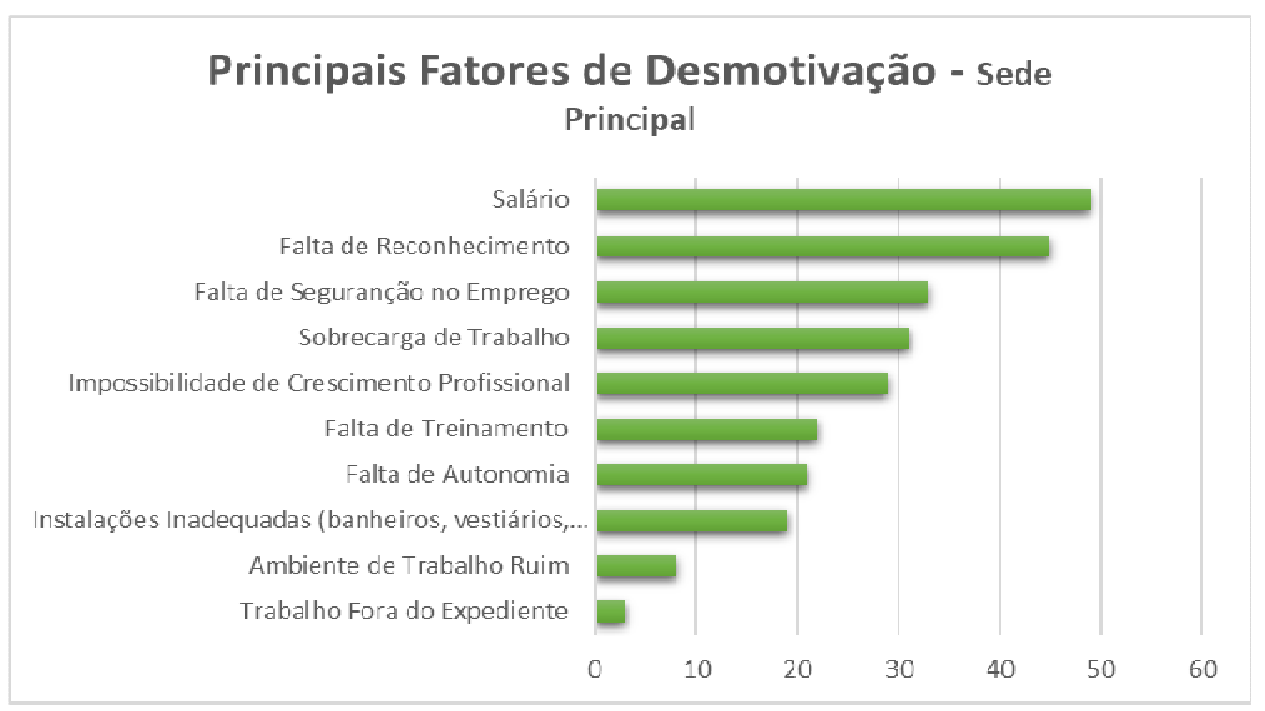

Figura 17: Gráfico da percepção dos respondentes da sede principal quanto aos fatores que causam desmotivação no trabalho.

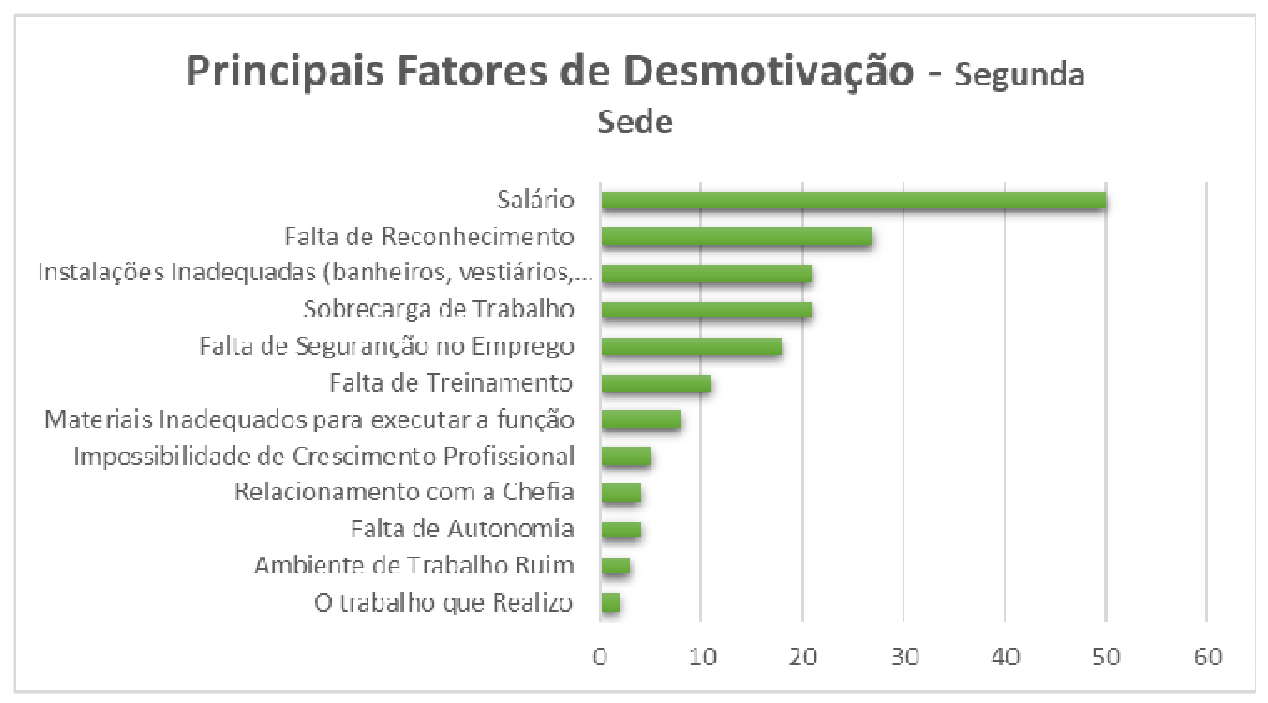

Figura 18: Gráfico da percepção dos respondentes da segunda sede quanto aos fatores que causam desmotivação no trabalho. 
Considerando os itens discriminados, esse tópico revelou que era necessário atuar em duas vertentes: falta de reconhecimento e regularização das leis trabalhistas.

\subsubsection{Falta de Reconhecimento}

Reconhecimento e valorização estão relacionados com autoestima. Um profissional que não é valorizado pelo seu trabalho, não recebe elogio, um feedback positivo ou qualquer tipo de reconhecimento profissional, provavelmente, após certo período de tempo na empresa, sofrerá uma perda de motivação. Isso fará também seu trabalho perder qualidade e até mesmo o interesse pela profissão diminuir.

Tentando evitar ao máximo esse cenário, foi sugerido as ações abaixo para minimizar os impactos desse item no dia-a-dia dos funcionários:

\section{O que fazer?}

1. Implementar planos de cargos e salários;

2. Implementar plano de carreira; e

3. Implementar plano de reconhecimentos.

\section{Como fazer?}

1. Levantando as descrições de cada cargo, definindo responsabilidades e competencias para atribuir escalas salariais e fazer as devidas adequações na folha.

2. Definindo metas setoriais e individuais visando justificar aumentos salariais e promoções; e

3. Realizando o Programa "Você faz a diferença", onde funcionários podem indicar outros funcionários a receberem gratificação por uma ação bem resolvida.

\section{Quem será o responsável?}

1. Recursos Humanos;

2. Recursos Humanos junto ao Gestor de cada área e o CEO; e

3. Recursos Humanos.

\section{Quando?}

1. Maio/2017; 
2. Janeiro/2017; e

3. Fevereiro/2017.

\subsubsection{Regularização de Leis Trabalhistas}

Tão importante quanto reconhecer um funcionário, é assegurar a ele que a empresa cumpre com todas as obrigações trabalhistas previstas na legislação atual. Isso é o item chave para o bom funcionamento da relação entre empresa e funcionário. Sendo assim, para manter a harmonia dessa parceria, foi proposto as melhorias abaixo:

\section{0 que fazer?}

1. Implementar banco de horas;

2. Regularizar pagamento de Insalubridade e Periculosidade;

3. Implementar a CIPA; e

4. Regularizar o gozo de férias.

\section{Como fazer?}

1. Homologando banco de horas junto ao sindicato e divulgando aos funcionários;

2. Levantamento dos riscos de cada função e análise pericial comprobatório do risco;

3. Promovendo eleição para cada CNPJ; e

4. Promover concientização dos gestores e funcionários referente a legislação trabalhista de férias e realizar programação anual concreta.

\section{Quem será o responsável?}

1. Departamento Pessoal;

2. Segurança do Trabalho e Departamento Pessoal;

3. Segurança do Trabalho e Departamento Pessoal; e

4. Recursos Humanos e Departamento Pessoal.

\section{Quando?}

1. Setembro/2017;

2. Fevereiro/2017;

3. Março/2017; e

4. Dezembro/2016. 


\section{Conclusões e contribuições do estudo}

A realização da pesquisa permitiu avaliar o clima organizacional da empresa mapeando problemas já conhecidos e outros novos para a diretoria. As críticas e sugestões apresentadas na pesquisa permitiram sanar muitos dos itens críticos que comprometiam um melhor clima organizacional.

Como tudo que é novo tem alguma resistência, foi complexo fazer com que os funcionários acreditassem no anonimato, mesmo isso sendo evidenciado a todo momento na aplicação da pesquisa. Esse item, em uma primeira pesquisa, pode comprometer a pesquisa, pois quando o funcionário não se sente à vontade para expor sua opinião o resultado pode ser distorcido. Só é possível mapear a extensão desse comprometimento nas respostas quando uma segunda pesquisa for aplicada e houver a comparação dos dados.

Vale ressaltar que é muito importante ter o apoio dos gestores, pois eles são os principais influenciadores de cada equipe: se o gestor não "comprar" a ideia dificilmente sua equipe comprará. Além dos gestores, é preciso estar atendo aos colaboradores que são líderes natos, eles também são influenciadores de opinião e precisaram saber claramente e objetivamente o que era o trabalho realizado. Outra questão é referente ao questionário físico, esse modo de questionário é viável quando o público chega a, no máximo, a 100 participantes, acima disso o trabalho de tabulação dos dados torna-se maçante e desmotivador.

Alguns problemas apresentados na pesquisa já eram conhecidos e foram passíveis de serem resolvidos com a proposição de ações simples trabalhando com recurso já disponível no momento, e alguns outros já estavam no planejamento do próximo ano. Foi interessante constatar que a maior parte dos problemas já era do conhecimento da diretoria, mas, de fato, nunca foram formalmente registrados e nunca houve um plano de 
ação estruturado para solucioná-los. Os planos de ação propostos visaram ao melhor retorno para cada item apontado negativamente na pesquisa e minimizando gastos não planejados no orçamento deste ano. Em função disso, as soluções foram voltadas a buscar dentro da organização os talentos que pudessem ajudar em cada item, essa atitude, de certa forma seria uma possibilidade de mantê-los motivados com novos projetos, objetivos e metas. Porém é necessário destacar que os percentuais satisfatórios definidos pela Diretoria estão totalmente fora da realidade e contexto atualmente praticado no mercado corporativo, pois dificilmente encontramos empresas com percentuais satisfatórios acima de $90 \%$.

É sempre possível que algumas adaptações sejam realizadas ao longo do desenvolvimento de cada ação, isso é natural, principalmente quando as ações são desempenhadas por um grupo de pessoas em que cada uma tem uma forma de pensar e agir e pode propor alguma outra ação complementar. Porém, diante de tudo que foi levando e analisado, o $\mathrm{RH}$ acredita que serão poucas.

Foram identificados também pontos positivos na pesquisa: mesmo considerando que a empresa tem muito a desenvolver para atender a todas as expectativas dos funcionários, eles a enxergam como um bom lugar para trabalhar e entendem que é sua a responsabilidade de contribuir para o crescimento e desenvolvimento da organização. Essa questão foi reforçada com o alto percentual de indicação de amigos e familiares para trabalhar na empresa (96\%). Além disso, foi gratificante ter a certeza de que os funcionários são engajados em suas atividades, gostam do que fazem e se empenham para entregar o melhor resultado possível. Muitos funcionários fizeram comentários positivos sobre a diretoria atual e, principalmente sobre a gestão do Presidente, informando que foi a gestão que melhor demonstrou a preocupação com os funcionários em relação a salários em dia, benefícios e instalações de trabalho, o sentimento era de que os funcionários se sentiram cuidados e respeitados.

Aplicar a pesquisa foi extremamente significativo para o crescimento profissional e pessoal da colaboradora que sugeriu a ideia, ela nunca 
havia participado de um projeto desse tamanho e relevância. Foi notória a entrega e emprenho para que todo o processo fosse gerido da forma mais clara, transparente, objetiva e confiável possível.

Cabe evidenciar que todas as soluções para desenvolvimento, aplicação, tabulação dos dados e análise das causas foram desenvolvidas internamente. Isso demonstra que mesmo a empresa não disponibilizando de recursos financeiros e espremendo bastante o prazo, a busca interna por uma solução viável e eficaz para obter o conhecimento do clima da organização é fator motivacional e inovador, servindo de exemplos para as demais empresas que se encontram na mesma situação ou similar. É nesse momento que se destacam os profissionais com maior perfil inovador.

Por outro lado, esse desenvolvimento interno da pesquisa ressalta a pobreza no referencial teórico do assunto, deixando, por algumas vezes, prevalecer a experiência de mercado dos profissionais no lugar de teorias concretas e comprovadas.

No resultado geral, a pesquisa foi muito satisfatória e o objetivo principal do trabalho foi atingido, que era identificar as oportunidades de melhorias em que a gestão de Recursos Humanos poderia atuar. E, além do objetivo principal, a pesquisa proporcionou uma melhor identificação da atuação das áreas integrantes do $\mathrm{RH}$ e a integração maior da área de Recursos Humanos com os departamentos e suas equipes, aproximando o contato, conhecendo o cotidiano, observando o convívio e proporcionando a criação da imagem de Recursos Humanos, como um setor presente, de credibilidade, aberto e atuante nos interesses dos funcionários, ativo na formação do processo de melhoria e empenhado em defender o melhor ponto de vista entre funcionário e empresa.

Para o clube, espera-se que essa pesquisa tenha criado um novo canal de comunicação com os colaboradores e que a área de Recursos Humanos tenha material suficiente para atuar de forma estratégica, mensurando suas ações através de processos que possam respaldar ao máximo sua atuação na empresa.

Aos demais, espera-se que esse artigo possa vir a ajudar as empresas que estejam em processo de criação/implantação da área de 
Recursos Humanos, com vistas a torná-la presente e atuante na empresa. Possa também auxiliar as empresas que já possuem uma área de Recursos Humanos sólida e desejam avaliar seu clima organizacional ou queiram aprimorá-lo. 


\section{Referências}

Avalio. Pesquisa de clima organizacional: como criar?. 2014. Disponível em: $<$ http://avalio.com.br/pesquisa-de-clima-organizacional> Acesso em: outubro de 2016.

Avalio. Pesquisa de Clima Organizacional: Veja as 10 perguntas-chave. 2014. Disponível em: <http://avalio.com.br/PESQUISA-DE-CLIMAORGANIZACIONAL-10-PERGUNTAS> Acesso em: outubro de 2016.

BISPO, Carlos Alberto Ferreira. Um novo modelo de pesquisa de clima organizacional. São Paulo, 2006. Escola de Engenharia de São Carlos da Universidade de São Paulo - USP.

BOWDITCH, James L. Elementos de Comportamento Organizacional. São Paulo: Pioneira, 1992.

CHIAVENATO, I. Gerenciando Pessoas. São Paulo: Makron Books, 1997.

CHIAVENATO, Idalberto. Gestão de pessoas; o novo papel dos recursos humanos nas organizações. Rio de Janeiro: Campus, 1999.

CODA, R. Estudo sobre clima organizacional traz contribuição para aperfeiçoamento de pesquisa na área de RH. São Paulo: Revista do Instituto de Administração da USP, n. 75, dez. 1993.

D'OTAVIANO, João Luis. Pesquisa de Clima Organizacional: Um estudo de caso em um laboratório farmacêutico. Goiânia, 2009. 75 p. Dissertação (Mestrado em Gestão e Estratégias de Empreendimentos) - Departamento de Desenvolvimento Regional: Faculdades Alves Faria - ALFA.

GILles, B. de Paula. Plano de Ação - 0 passo a passo da ideia à concretização de seus objetivos!. Treasy - Planejamento e Controladoria, 2016. Disponível em: <https://www.treasy.com.br/blog/plano-de-acao> Acesso em: novembro de 2016.

GONÇALVES, Alexis P. Saiba como anda seu clima organizacional. São Paulo: Revista Controle da Qualidade, v.7, n. 67, p.105-107, dez. 1997.

KAHALE, Flávia. Pesquisando a Motivação: a pesquisa de clima organizacional. Instituto MVC. Disponível em: <http://www.institutomvc/portfolio/clima_org/clima_motiv1.htm> Acesso em 20 de outubro de 2017. 
LUZ, Ricardo. Gestão do Clima Organizacional. Rio de Janeiro: Qualitymark, 2003.

MARTINS, Rosemeary. O que é PDCA?. Blog da Qualidade, 2012. Disponível em: <http://www.blogdaqualidade.com.br/o-que-e-pdca/> Acesso em: 10 de novembro de 2017.

NASCIMENTO, Adriano Gagner Gonçalves. A Utilização da < Metodologia do Ciclo PDCA no Gerenciamento da Melhoria Continua. Minas Gerais, São João Del Rei, 2011. Disponível em: <http://www.icap.com.br/biblioteca/175655010212_Monografia_Adriano_Fagner. pdf> Acesso em: 01 de novembro de 2017.

SANTOS, Lisiane Carvalho dos. Aplicação da Pesquisa de Clima Organizacional em uma Empresa Varejista. Disponível em: <http://www.administradores.com.br/artigos/carreira/aplicacao-da-pesquisa-declima-organizacional-em-uma-empresa-varejista/67618/> Acesso em 02 de novembro de 2017.

SurveyMonkey. Questionário para pesquisa de clima organizacional. Disponível em: <https://pt.surveymonkey.com/mp/employee-satisfactionsurveys/> Acesso em: outubro de 2016.

Vanderhulst. PDCA: uma ferramenta no processo de melhoria contínua para a sua empresa. Maio de 2017. Disponível em: $<$ https://vanderhulst.com.br/blog/2017/05/05/pdca-uma-ferramenta-no-processode-melhoria-continua-para-a-sua-empresa/> Acesso em: 13 de novembro de 2017.

VIEIRA, Rufina Gustmann. A Influência do Clima Organizacional nas Empresas e nas Pessoas. Santa Catarina, SC. Curso de Especialização em Gestão Estratégica em Recursos Humanos. Instituto Catarinense de PósGraduação - $\quad$ ICPG. Disponível em: < http://www.posuniasselvi.com.br/artigos/rev04-04.pdf> Acesso em: 02 de novembro de 2017. 


\section{Anexo 1: Divulgação - O que é Pesquisa de Clima?}

\section{Divulgação 1 Funcionários - 0 que é Pesquisa de Clima?}

Vem aí a FalaX, nossa Pesquisa de Clima Organizacional!!!

Falando nisso...

Você sabe o que é pesquisa de clima organizacional (PCO)?

A PCO é uma valiosa ferramenta de gestão estratégica. Através dela é possível identificar o grau de satisfação e motivação dos colaboradores. O resultado permite a implantação e realização de ações para crescimento e desenvolvimento das pessoas com a máxima produtividade e qualidade.

A pesquisa de clima organizacional pode ser dividida em etapas:

$1^{\underline{a}}$ etapa: coleta de dados através de formulários.

$2^{\underline{a}}$ etapa: tabulação dos dados coletados.

$3^{a}$ etapa: interpretação e análise estatísticas dos dados.

4⿳亠丷厂 etapa: elaboração do relatório final.

$5^{\text {a }}$ etapa: identificação dos pontos fortes e fracos.

6⿳亠丷厂 etapa: plano de ação para melhoria do clima organizacional.

Em relação aos assuntos, podem ser abordadas diversas temáticas, como trabalho, relacionamento interpessoal, integração setorial, comunicação, trabalho em equipe, estilos de liderança, políticas, condições de trabalho e do ambiente, imagem da empresa. É possível ainda incluir outros temas de acordo com a necessidade da empresa.

Por ser uma pesquisa aberta, é possível personalizar a pesquisa de clima organizacional conforme as necessidades.

Fiquem atentos que em breve teremos mais informações!

Entre no Clima! Queremos ouvir sua voz!

Recursos Humanos 


\section{Anexo 2: Divulgação - Qual a importância e objetivo do clube?}

\section{Divulgação 2 Funcionários - Qual a importância e objetivo do clube?}

Vem aí a FalaX, nossa Pesquisa de Clima Organizacional!!!

Falando nisso...

Você sabe quais os principais objetivos da pesquisa de clima organizacional?

Os principais objetivos da pesquisa é identificar processos que sobrecarregam e atrapalham a equipe, propor treinamentos conforme interesse e necessidade, identificar problemas de relacionamento, além de avaliar e possibilitar sugestões de novas políticas de recursos humanos.

A PCO permite ainda a criação de uma base de informações sobre seus colaboradores e empresa, além de possibilitar a identificação de pontos positivos e negativos que impactam no clima organizacional.

Para o clube, a FalaX tem como principal objetivo identificar o grau de satisfação dos colaboradores e propor ações visando um bom clima organizacional, o que não só aumenta a produtividade e diminui a rotatividade de funcionários, como também possibilita criar um melhor ambiente de trabalho. Colaboradores satisfeitos e motivados produzem mais e melhor.

Fiquem atentos que em breve teremos mais informações!

Entre no Clima! Queremos ouvir sua voz!

Recursos Humanos 


\section{Anexo 3: Divulgação - Como será a pesquisa?}

\section{Divulgação 3 Funcionário - Como será a pesquisa?}

Vem aí a FalaX, nossa Pesquisa de Clima Organizacional!!!

Falando nisso...

Você sabe como funciona uma pesquisa?

Para que uma empresa se torne moderna, com produtos ou serviços competitivos e com qualidade comprovada, com a imagem consolidada tanto pelos clientes como pelos seus funcionários, como o mercado exige atualmente, é necessário que a empresa mantenha um bom relacionamento não somente com os clientes, mas também com seus funcionários. Uma forma de avaliar esse relacionamento é aplicando uma pesquisa de clima organizacional.

Todos os funcionários receberão o material que faz parte dessa pesquisa, quanto mais funcionários participarem, mais real será o cenário traçado e poderá ser feito um melhor trabalho para se corrigir eventuais distorções que estejam ocorrendo no relacionamento entre a empresa e os funcionários.

Em todas as folhas do questionário você vai verificar que não existe qualquer espaço reservado para a sua identificação.

Você jamais poderá ser prejudicado por ter participado da pesquisa e ter fornecido informações valiosas para a avaliação do relacionamento entre a empresa e os funcionários, mesmo porque, como não é exigida qualquer identificação, não há a possibilidade e nem a intenção de se saber a avaliação individual de qualquer funcionário.

Esse material que você e todos os demais funcionários irão receber e que compõe a pesquisa é composto por uma ficha de pesquisa e uma folha avulsa para as suas observações. Nas fichas de pesquisa são levantados quais são os fatores que influenciam o relacionamento entre os funcionários e a empresa. Esses fatores influenciam o nosso 
comportamento, as nossas decisões e as nossas atitudes de forma direta ou indireta, normalmente alterando para melhor ou para pior o nosso estado de ânimo, o nosso humor e a nossa motivação. Existem dois tipos de fatores de influência: os internos e os externos.

Os fatores internos de influência são os que se originam dentro da própria empresa, eles podem ser trabalhados na empresa para que produzam resultados positivos tanto para os funcionários quanto para a empresa.

Os fatores externos de influência são os que se originam fora da empresa, porém eles exercem influência nos funcionários dentro da empresa, por isso não podem ser desprezados. Esses fatores podem ser trabalhados pela empresa não na sua origem, mas nos efeitos que produzem.

Após o levantamento da situação de cada item por meio da pesquisa, será possível se elaborar planos de ação para proporcionar melhorias nos itens que receberem uma avaliação ruim e reforçar os itens que receberem uma avaliação positiva.

Para cada item que consta nas duas fichas de pesquisa existem algumas alternativas de resposta. Você precisará marcar com um $\mathrm{X}$ uma única alternativa para cada item.

Haverá ainda uma folha avulsa que poderá ser usada para opiniões, observações ou demais sugestões.

Você deverá preencher as fichas de pesquisa na empresa. O mais importante é que você e os demais funcionários se manifestem de forma sincera e sem qualquer interferência ou influência de quem quer que seja (chefe, colegas de trabalho ou familiares), isto para que os dados fornecidos retratem da forma mais fiel possível a realidade do relacionamento entre a empresa e os funcionários e se possa traçar bons planos de ação para se corrigir as distorções.

É importante que todos os itens sejam preenchidos.

Contamos com você!

Entre no Clima! Queremos ouvir sua voz!

Recursos Humanos 


\section{Anexo 4: Divulgação - Convite para participação}

\section{Divulgação 4 Funcionário - Convite para participação}

Vem aí a FalaX, nossa Pesquisa de Clima Organizacional!!!

\section{Você diz o que pensa.}

0 "Clube" pensa sobre o que você diz!

\section{FalaX 2016}

Conhecer você é entender a todos nós.

É a hora de conhecermos o que fazemos de melhor e o que ainda precisamos melhorar para tornar nosso ambiente de trabalho cada vez mais agradável.

Do dia $07 / 11$ a $10 / 11$, será disponibilizada a primeira Pesquisa de Clima 2016 do XXX (NOME DA EMPRESA).

Contamos com sua participação para juntos construir a empresa que todos desejam! 


\section{Anexo 5: Ficha de Instruções de Preenchimento}

\section{INSTRUÇÕES DE PREENCHIMENTO}

Você está recebendo o questionário de Pesquisa de Clima Organizacional. Seu preenchimento é muito fácil.

Esta pesquisa tem como objetivo conhecer sua opinião sobre diferentes aspectos de nossa empresa.

Queremos, com seus resultados, melhorar a qualidade de vida dos funcionários proporcionando um melhor ambiente de trabalho.

Sua participação é fundamental para o sucesso do projeto.

Não é necessário fazer qualquer tipo de identificação no questionário, preservando, assim, seu anonimato.

Leia com atenção cada pergunta e use toda sinceridade ao responder.

Assinale com um "X" a resposta que você escolher. Marque apenas uma resposta.

Ao final, uma folha avulsa estará disponível para que você contribua com as observações, opiniões e sugestões que julgar necessário.

Entre no Clima! Queremos ouvir sua voz!

Recursos Humanos 


\section{Anexo 6: Ficha Principal - Questionário}

\section{FICHA PRINCIPAL}

\section{QUALIFICAÇÕES GERAIS}

- Sexo: ( ) Feminino ( ) Masculino

- $\quad$ Estado Civil: ( ) Solteiro(a) ( ) Casado(a)
( )União Estável
( ) Viúvo(a)
( ) Divorciado(a)

- Idade: ( ) Entre 18 e 25 anos

( ) Entre 25 e 35 anos

( ) Entre 35 e 45 anos

( ) Acima de 45 anos

- $\quad$ Tem filhos: ( ) Não ( ) Sim Quantos?

- $\quad$ Qual sua renda familiar? Considere a renda de todas as pessoas que moram com você. Salário Mínimo: $R$ \$ 880,00

( ) De 1 a 3 salários mínimo

( ) De 3 a 5 salários mínimo

( ) de 5 a 10 salários minimo

( ) Acima de 10 salários mínimo

- $\quad$ A quanto tempo trabalha no Fluminense?
( ) até 2 anos
( ) de 2 a 5 anos
( ) de 5 a 10 anos
( ) acima de 10 anos

\section{SAÚDE}

Considerando sua condição de saúde, como você avalia: Seu estado físico:
( ) Ótimo ( ) Bom ( ) Razoável ( ) Ruim ( ) Péssimo Seu estado mental:
( ) Ótimo ( ) Bom ( ) Razoável ( ) Ruim ( ) Péssimo Seu estado emocional

( ) Ótimo ( ) Bom ( ) Razoável ( ) Ruim ( ) Péssimo 


\section{CONVIVÊNCIA FAMILIAR}

- O relacionamento com meu cônjuge/companheiro é:

( ) Ótimo ( ) Bom ( ) Razoável ( ) Ruim ( ) Péssimo

O relacionamento com meus filhos é:

( ) Ótimo ( ) Bom ( ) Razoável ( ) Ruim ( ) Péssimo

Você dispõe atenção suficiente para sua família?

( ) não ( ) mais ou menos ( ) sim

\section{FÉRIAS E LAZER}

- $\quad$ Estou satisfeito com as minhas últimas férias.
( ) não ( ) sim

- $\quad$ Estou planejando para que as minhas próximas férias sejam muito boas.

( ) não ( ) sim

\section{AUTONOMIA}

Você tem liberdade para fazer o seu trabalho da forma como considera melhor?

( ) Sempre ( ) Quase sempre ( ) Raramente ( ) Nunca

- A empresa exige um procedimento rígido para execução das atividades pertinentes as suas funções?

( ) Sempre ( ) Quase sempre ( ) Raramente ( ) Nunca

- Você que organiza sua rotina de trabalho para melhor aproveitamento de suas atividades?

( ) Sempre ( ) Quase sempre ( ) Raramente ( ) Nunca Você toma decisões pela empresa?

( ) Sempre ( ) Quase sempre ( ) Raramente ( ) Nunca

\section{RESPONSABILIDADE}

- $\quad$ Até que ponto você cumpre as responsabilidades que são destinadas à sua função?

( ) Sempre ( ) Quase sempre ( ) Raramente ( ) Nunca

- Você considera que é sua responsabilidade contribuir para o sucesso da empresa?

\section{( ) Sim ( ) Não}

- Você desempenha seu trabalho buscando obter resultados melhores do que aqueles esperados pela empresa?

( ) Sempre ( ) Quase sempre ( ) Raramente ( ) Nunca Você se considera comprometido com suas atividades?

( ) Sempre ( ) Quase sempre ( ) Raramente ( ) Nunca 


\section{REALIZAÇÃO PROFISSIONAL}

- $\quad$ Você está satisfeito com o seu cargo?

( ) Sim ( ) Não ( ) Mais ou menos

O seu trabalho Ihe dá um sentimento de realização profissional?

( ) Sempre ( ) Quase sempre ( ) Raramente ( ) Nunca

\section{QUANTIDADE E QUALIDADE DE TRABALHO}

Você se sente satisfeito em relação ao volume de trabalho que realiza?

( ) Sim ( ) Não ( ) Mais ou menos

- A qualidade do trabalho é considerada mais importante do que a sua quantidade?

( ) Sempre ( ) Quase sempre ( ) Raramente ( ) Nunca

- Você acha que o seu trabalho realizado atualmente poderia ser melhorado?
( ) Muito pouco
( ) Mais ou menos
( ) Muito

\section{COMUNICAÇÃO}

- $\quad$ Como a direção da empresa se comunica com seus funcionários?

( ) Adequadamente ( ) Razoavelmente ( ) Inadequadamente

- $\quad$ Os funcionários sentem-se seguros em dizer o que pensam?

( ) Sempre ( ) Quase sempre ( ) Raramente ( ) Nunca

- A empresa é aberta a receber e reconhecer as críticas, opiniões e contribuições de seus funcionários?

( ) Sempre ( ) Quase sempre ( ) Raramente ( ) Nunca

- $\quad$ As orientações que você recebe sobre o seu trabalho são claras e objetivas?

( ) Sempre ( ) Quase sempre ( ) Raramente ( ) Nunca

\section{REMUNERAÇÃO}

- Você está satisfeito com o seu salário atual?

( ) $\operatorname{Sim}$ ( ) Não

- Você considera a sua remuneração adequada ao trabalho que você faz?

( ) $\operatorname{Sim}$ ( ) Não

- Você acha que a empresa remunera adequadamente os funcionários?

( ) Sempre ( ) Quase sempre ( ) Raramente ( ) Nunca 


\section{CARREIRA}

Você acredita na oportunidade de crescimento em sua carreira?

( ) Sim ( ) Não ( ) Mais ou menos

- $\quad$ Você se sente apto para assumir maiores ou mais responsabilidades?

( ) Sim ( ) Não ( ) Mais ou menos

Você gostaria de trabalhar em outro departamento da empresa?

( ) Sim ( ) Não

A empresa oferece oportunidades para o seu desenvolvimento e crescimento profissional?

( ) Sempre ( ) Quase sempre ( ) Raramente ( ) Nunca

\section{RELACIONAMENTOS COM A CHEFIA}

- Você se sente respeitado pelo seu chefe/gestor/gerente?

( ) Sempre ( ) Quase sempre ( ) Raramente ( ) Nunca

Você respeita seu chefe/gestor/gerente?

( ) Sempre ( ) Quase sempre ( ) Raramente ( ) Nunca

Você considera seu chefe/gestor/gerente um bom profissional?

( ) Sim ( ) Não ( ) Mais ou menos

O seu chefe/gestor/gerente é receptivo às sugestões de mudança?

( ) Sempre ( ) Quase sempre ( ) Raramente ( ) Nunca

\section{RELACIONAMENTO INTERPESSOAL}

- $\quad$ Existe um relacionamento de cooperação entre os departamentos da empresa?

( ) Sim ( ) Não

Como você considera o relacionamento entre os funcionários da empresa?

( ) Ótimo ( ) Bom ( ) Razoável ( ) Ruim

\section{VALORIZAÇÃO PROFISSIONAL}

- $\quad$ Você se sente valorizado pela empresa?

( ) Sim ( ) Não ( ) Mais ou menos

- Você considera que o seu potencial de realização profissional tem sido adequadamente aproveitado?

( ) Sempre ( ) Quase sempre ( ) Raramente ( ) Nunca

A empresa reconhece os bons funcionários?

( ) Sempre ( ) Quase sempre ( ) Raramente ( ) Nunca

\section{TREINAMENTO/DESENVOLVIMENTO}


- Você recebeu o devido treinamento para a execução de seu cargo?

( ) Sim ( ) Não ( ) Mais ou menos

- $\quad$ A empresa investe em treinamentos necessários para o desenvolvimento profissional e pessoal de seus funcionários?

( ) Sim ( ) Não ( ) Mais ou menos

- $\quad$ O treinamento que você recebe o capacita a fazer bem o seu trabalho?

( ) Sempre ( ) Quase sempre ( ) Raramente ( ) Nunca

- A empresa investe em treinamento/desenvolvimento para que você tenha um aprendizado contínuo?

( ) Sempre ( ) Quase sempre ( ) Raramente ( ) Nunca

\section{ESTABILIDADE NO EMPREGO}

- $\quad$ Você se sente seguro em relação à estabilidade de seu emprego?

( ) $\operatorname{Sim}$ ( ) Não ( ) Mais ou menos

- $\quad$ Os funcionários da empresa sentem-se seguros quanto à estabilidade no emprego?

( ) Sim ( ) Não ( ) Mais ou menos

\section{CONDIÇÕES FÍSICAS DE TRABALHO}

- $\quad$ As condições ambientais do seu local de trabalho são satisfatórias?

$\begin{array}{ll}\text { Temperatura } & \text { ( ) } \operatorname{Sim} \text { ( ) Não } \\ \text { Espaço } & \text { ( ) } \operatorname{Sim} \text { ( ) Não } \\ \text { Mobiliário } & \text { ( ) } \operatorname{Sim} \text { ( ) Não } \\ \text { Higiene } & \text { ( ) } \operatorname{Sim} \text { ( ) Não } \\ \text { Instalações sanitárias } & \text { ( ) } \operatorname{Sim} \text { ( ) Não }\end{array}$

\section{IMAGEM DA EMPRESA}

- Considera a empresa um bom lugar para trabalhar?

( ) $\operatorname{Sim}$ ( ) Não

- $\quad$ Você indicaria um amigo para trabalhar na sua empresa?

( ) Sim ( ) Não

- Você considera a empresa ética com seus funcionários/clientes/ parceiros?

( ) Sempre ( ) Quase sempre ( ) Raramente ( ) Nunca

Os gestores da empresa dão bons exemplos aos seus funcionários?

( ) Sempre ( ) Quase sempre ( ) Raramente ( ) Nunca 


\section{TRABALHO EM EQUIPE}

- $\quad$ Os assuntos importantes são debatidos em equipe?

( ) Sempre ( ) Quase sempre ( ) Raramente ( ) Nunca

A empresa estimula o trabalho em equipe?

( ) Sempre ( ) Quase sempre ( ) Raramente ( ) Nunca

\section{FATORES MOTIVACIONAIS/FATORES DESMOTIVADORES}

- Indique três principais fatores que geram mais insatisfação no seu trabalho. Coloque número 1 no fator que gera mais insatisfação, número 2 no segundo maior fator de insatisfação e o número 3 para o terceiro maior fator de insatisfação.

( ) Falta de reconhecimento

( ) Falta de segurança no emprego

( ) Impossibilidade de crescimento profissional

( ) Falta de autonomia

( ) Ambiente de trabalho ruim

( ) O trabalho que realizo

( ) Relacionamento com a chefia

( ) Falta de treinamento

( ) Sobrecarga de trabalho

( ) Instalações inadequadas (banheiros, vestiários etc.)

( ) Salário

( ) Outros:

Indique as duas principais razões pelas quais você trabalha na empresa. Coloque número 1 na principal e número 2 na segunda mais importante.

( ) Salário

( ) Benefícios oferecidos pela empresa

( ) Estabilidade no emprego

( ) Relacionamento com a chefia

( ) O trabalho que realizo

( ) A falta de opção de outro emprego

( ) Ambiente de trabalho

( ) Prestígio da empresa

( ) Autonomia no trabalho

( ) Possibilidade de treinamento

( ) Reconhecimento

( ) As chances de progresso profissional 


\section{Anexo 7: Ficha Avulsa - Folha para observações}

\section{FOLHA AVUSA PARA SUAS OBSERVAÇÕES}

Nessa folha você pode relatar as suas observações, os seus comentários, as suas reivindicações, as suas queixas, as suas críticas, as suas sugestões ou os seus elogios a algum dos itens que constam nas duas fichas de pesquisa, referente à empresa, ao departamento ou à seção onde você trabalha, ao seu chefe imediato, à estrutura hierárquica, ao sistema de trabalho, às instalações, às condições de trabalho, às normas de trabalho, à forma de tratamento recebida de seus chefes, aos seus colegas de trabalho, ao seu ambiente de trabalho, etc. Sinta-se à vontade para relatar e revelar tudo o que desejar sem constrangimentos. Lembre-se que você não precisa se identificar, a menos que queira fazêlo. As suas sinceras observações serão valiosas para a pesquisa. Podem ser utilizadas quantas linhas ou quantas folhas forem necessárias. 